\title{
LAW IN THE CONTROL OF TERRORISM AND INSURRECTION: THE BRITISH LABORATORY EXPERIENCE
}

\author{
Joseph W. Bishop, Jr.*
}

\begin{abstract}
Abraham Lincoln said in 1864, "It has long been a grave question whether any Government, not too strong for the liberties of its people, can be strong enough to maintain its existence in great emergencies." "The question still remains in doubt, although Great Britain and the United States have so far maintained their existence without abolishing the liberties of their people. Many less durable democracies have failed the test, often when the only "emergency" was a threat that their present rulers might fall from power by democratic processes. Lincoln spoke toward the end of the most formidable insurrection ever faced and overcome by a constitutional democracy, in which he had had constantly to balance the needs of national survival against the liberties of the citizen. He had taken many drastic actions, sometimes without the authority of Congress, including suspension of the writ of habeas corpus and military arrest, internment, and trial of civilians. ${ }^{2}$ But the United States emerged from the Civil War, as it did from subsequent foreign wars, still a constitutional democracy, with the citizen's rights pretty much intact.

No democracy today faces an internal crisis of such magnitude as the American Civil War. But many of them, including England, France, West Germany, Italy, Israel, and Japan, are plagued by terrorists calling themselves urban guerrillas, or freedom fighters, or People's Armies, or whatever menacing and grandiloquent title happens to please their fevered fancies. The violent dissidents are, of course, an enormously diverse group; some have more or less definite, in a few cases arguably just, political goals; most of them profess some sort of Marxist philosophy, often of a highly idiosyncratic variety that would startle Marx, Engels, or even Mao, as much as Anabaptism startled Luther; some seem hardly more than bands of homicidal maniacs, reminiscent
\end{abstract}

\footnotetext{
* Richard Ely Professor of Law, Yale University School of Law. Much of the research on which this article was based was performed while the author was Visiting Fellow at Clare Hall, Cambridge University, and was conducted with the aid of grants from the John Simon Guggenheim Memorial Foundation and the Council for International Exchange of Scholars. The author expresses his gratitude to all these institutions.

1. See 9 J. Nicolay \& J. Hay, Abraham Lincoln: A History, 380 (1890).

2. See, e.g. Ex parte Milligan, 71 U.S. (4 Wall.) 2 (1866); Ex parte Vallandigham, 68 U.S. (1 Wall.) 243 (1864); Ex parte Merryman, 17 F. Cas. 144 (C.C.D.Md. 1861) (No. 9487); 6 C. FAIRman, Reconstruction and Reunion 1864-88, at 192-222, 491 (1971).
} 
of the nihilists of the last century, for whom death and destruction are pleasant and edifying ends in themselves. ${ }^{3}$ Generalizations are thus difficult: About the only thing all the extremist groups (some of which can hardly be called "organizations") have in common is a passionate hatred of the constituted authorities of their own country and its allies and friends, and a corollary willingness to stop at absolutely nothing to hasten the advent of their own notion of the millennium.

Another generalization may be ventured upon: The terrorist poses peculiar and difficult problems for the police, the courts, and the rest of the ordinary civilian apparatus of law enforcement. He is by definition a zealot, who rarely makes Benthamite calculations balancing benefits against risks. Unlike the ordinary criminal, he frequently has little concern for his own skin. He may be part of an organization formidable enough to intimidate witnesses and jurors, if not the police and the judges, and able also to kidnap hostages or hijack airplanes in order to extort his release if he is caught. In some places he can count on the sympathy or fear of a part of the population large enough to give him a safe base of operations. Often he can rely on sources outside the country to furnish him money, arms, and sanctuary. Finally, terrorists can wreak havoc out of all proportion to their numbers on a highly industrialized society whose very life depends on the functioning of vulnerable utilities and factories. There is even the unpleasant possibility that some of the fanatics may soon have at their disposal nuclear weapons at least comparable to those which devastated Hiroshima and Nagasaki.

It is only in polities in which, by tradition or written constitution, the people actually have liberties that Lincoln's question is relevant. No totalitarian government with a ruthless and efficient secret police, possessing unlimited powers of surveillance, censorship, arrest, interrogation, search and seizure, and imprisonment or execution without trial, has much to fear from dissidents-violent or otherwise. About the most extreme form of political dissent in Russia is the surreptitious production and circulation of uncensored tracts, and even that requires rare and remarkable courage. Disagreement with the Thoughts of Chairmen Mao and Hua, so far as any exists, is so muted as to be inaudible. Similar tranquility prevails in almost all the Communist countries, even Czechoslovakia. Right-wing dictatorships and oligarchies seem today less thoroughly repressive than Nazi Germany or Fascist Italy, but at least the governments of such nations as Chile or Brazil encounter no legal or philosophical difficulties in taking whatever measures they deem necessary to keep the opposition quiet and ineffectual.

The two oldest democracies, the United Kingdom (of Great Britain and Northern Ireland) and the United States, naturally have the longest experi-

3. A partial catalogue of the better-known terrorist organizations is contained in STAFF of House Comm. on Internal. Security, 93D Cong., 2D Sess., Terrorism (Comm. Print 1974). 
ence of trying to preserve what the latter's Constitution calls "domestic Tranquillity" in great emergencies without resorting to methods that themselves pose a greater threat to constitutional democracy than does the emergency. The United States has had to deal with many crises and emergencies, of which the Civil War was only the greatest. In recent years, though we are not immune to the terrorist plague, the federal and state governments have so far been faced only with relatively small and ill-organized bands whose activities, however murderous, have not been on a scale with which the ordinary procedures of law enforcement could not cope. But the United Kingdom has since 1969 had to deal with a real armed rebellion, amounting to a guerrilla war (complicated by intestine wars among the guerrillas themselves) in Northern Ireland, which has sometimes spilled over into England itself.

The main purpose of this article is to describe the British reaction to that crisis. I shall describe the historical and constitutional context in which the British Government has operated; the peculiar problems posed for law enforcement by insurrection just short of open civil war; the powers which Parliament has given to the Government to deal with such problems in past and present emergencies; the use which the Government has made of those powers and the tactics (including extensive use of military force) it has employed with (and occasionally without) explicit Parliamentary sanction; and the role of various Royal Commissions and the courts. Finally, I shall consider briefly the present state of American law, constitutional and statutory, on the control of serious domestic violence, and discuss what lessons the United States may learn from the British experience. ${ }^{4}$

The Crown (that is, the Government) has common-law powers to deal with emergencies for which Parliament has not provided, but in modern times British Governments have had few occasions to rely on that prerogative. In World War I, internment of alien enemies was at first justified as an exercise of the prerogative. ${ }^{5}$ In the Irish Troubles of 1920 and 1921 , the trial of civilians by military commissions (as distinct from courts-martial, which were bound by much stricter rules of procedure and evidence than the nonjudicial military commissions), although not authorized by any Act of Parliament, was originally based on the Government's inherent power (exercised through the General Officer Commanding British Forces in Ireland) to take such steps as it deemed necessary to deal with the existing state of "war or armed rebellion."6 In 1942 the British military commander in Burma, since there was no applicable statute, exercised the Crown prerogative by ordering the destruc-

4. The classic work in the subject is C. Fairman, The Law of Martial Rule (2d ed. 1943). The reader is referred to that book for a detailed and careful account of the development of British and American law down to the middle of World War II.

5. The King v. Vine Street Police Station Superintendent, ex parte Liebmann, [1916] 1 K.B. 268; see S. de Smith, Judicial. Review of Administrative Action 254, 270, 276 (3d ed. 1973).

6. See Osborough, Law in Ireland 1916-26, 23 N. IR. L.Q. 48 (1972). 
tion of British private property in order to keep it from falling into the hands of the Japanese. The House of Lords held that "the prerogative certainly covers doing all those things in an emergency which are necessary for the conduct of war," but three of the five judges held also that the owner of the destroyed property had a common-law right to be paid its value. ${ }^{8}$

The net effect of these episodes, however, was to emphasize the supremacy of Parliament and the superior reliability of its Acts as a basis for emergency action. The question of the Crown's authority to intern not only enemy aliens but British subjects was mooted when the House of Lords in the following year read such power into the Defence of the Realm Consolidation Act, 1914. ${ }^{9}$ The Irish courts split on the Crown's power, in the name of martial law, to try civilians by military commission and sentence them to death, but the difference of opinion centered on whether that power had been limited by Act of Parliament. ${ }^{10}$ And Parliament promptly and retroactively reversed the House of Lords on the common-law right to compensation of the owner of property destroyed in a wartime emergency. ${ }^{11}$ Whatever the residual powers of the Crown may be when Parliament has not spoken, there is no dispute that Parliament can limit those powers or prescribe the manner of their exercise. ${ }^{12}$

This situation is generally very satisfactory from the standpoint of British governments who, of course, by definition command a majority of the House of Commons. For obvious political reasons Parliament is usually more inclined than Congress (particularly when Congress is controlled by one party and the White House by the other) to give the Executive pretty much what the latter thinks is necessary to deal with an emergency, imposing few restrictions beyond those the Government itself suggests. Thus, the statutory grants of power have often been phrased in sweeping terms, particularly when the emergency was large, close at hand, and threatening. The World War I Defence of the Realm Acts $^{13}$ started by providing that "His Majesty in Council

7. Burmah Oil Co. v. Lord Advocate, [1965] A.C. 75, 100. See Note, The Burmah Oil Affair, 79 HARv. L. Rev. 614 (1966).

8. [1965] A.C. at 75. The majority rejected and the dissenters followed the reasoning of a majority of the United States Supreme Court in a case presenting almost identical facts. United States v. Caltex, Inc., 344 U.S. 149 (1952). The American holding rested on the majority's construction of the provision of the fifth amendment that "private property [shall not] be taken for public use, without just compensation" as drawing a distinction between destruction and "taking."

9. 5 Geo. 5, c. 8; The King (Zadig) v. Halliday, [1917] A.C. 260. See note 207 infra, and accompanying text.

10. Compare The King v. Allen, [1921] 2 I.R. 241 (K.B.) with Egan v. Macready, [1921] 1 I.R. 265 (Ch.).

11. War Damage Act, 1965 , c. 18.

12. See, e.g., S. DE SMITH, supra note 5, at 253-54; Carr, Crisis Legislation in Britain, 40 Colum. L. Rev. 1309, 1310 (1940).

13. Defence of the Realm Consolidation Act, 1914, 5 Geo. 5, c. 8, as amended by Defence of the Realm (Amendment) Act, 1915, 5 Geo. 5, c. 34. See generally Cotter, Constitutionalizing Emergency Powers: The British Experience, 5 Stan. L. Rev. 382 (1953). 
[i.e., the Government] has power during the continuance of the present war to issue regulations for securing the public safety and the defence of the realm," and even went so far as to authorize the court-martialing of civilians accused of violating several categories of such regulations. ${ }^{14}$

The first section of the Emergency Powers (Defence) Act, 1939, ${ }^{15}$ passed in immediate contemplation of World War II, granted the Government still broader powers, including power by an Order in Council to suspend or modify even Acts of Parliament, except for the Emergency Powers Act itself. ${ }^{16}$ The Act, unlike the World War I statute, explicitly authorized internment of "persons whose detention appears to the Secretary of State [i.e., the Home Secretary] to be expedient in the interests of public safety or the defence of the realm." British subjects and resident aliens for the duration of World War II and its immediate aftermath ${ }^{17}$ were regulated more thoroughly than American citizens and, in some ways, than the inhabitants of Nazi Germany. ${ }^{18}$

Other statutes, relevant to several categories of emergencies other than war and granting powers somewhat less extensive, remain on the books, available if needed. The most important, at least potentially, is the Emergency Powers Act, $1920,{ }^{19}$ which, although originally intended and employed to deal with crippling strikes, is worded so broadly as to give the Government sweeping powers in emergencies due to other causes, such as natural disasters or terrorist attacks on essential supplies and services. ${ }^{20}$

14. In fact, however, fewer than 40 civilians seem to have been tried by court-martial during World War I. See Cotter, supra note 13, at 390. The Defence of the Realm (Amendment) Act, 1915,5 Geo. 5, c. 34 , gave concurrent jurisdiction to civilian courts.

15. $2 \& 3$ Geo. 6, c. 62 .

16. The Emergency Powers (Defence) Act, 1940, 3 \& 4 Geo. 6, c. 20, further exempted acts passed after its own date.

17. The act and such of the regulations under it as had not already been revoked were repealed by the Emergency Laws (Repeal) Act, 1959, c. 19, and the Emergency Laws (ReEnactments and Repeals) Act, 1964, c. 60.

18. See Cotter, supra note 13 , at $403,406,409$. There were 377 Defence Regulations and more than 10,000 regulations, rules, and orders made pursuant to authority delegated by Defence Regulations. There were no less than $1,275,889$ convictions for offenses (most of them, of course, minor infractions) against the regulations, and several thousand people, including both aliens and British subjects, were interned.

19. $10 \& 11$ Geo. 5, c. 55, as amended by the Emergency Powers Act, 1964, c. 38.

20. The Act provides that, "If at any time it appears to Her Majesty [i.e., the Government] that there have occurred, or are about to occur, events of such a nature as to be calculated, by interfering with the supply and distribution of food, water, fuel, or light, or with the means of locomotion, to deprive the community, or any substantial portion of the community, of the essentials of life, Her Majesty may, by proclamation . . . declare that a state of emergency exists." Thereupon the Government by Order in Council may make such regulations, and confer such powers on the civilian and military authorities, as it "may deem necessary for the preservation of the peace, for securing and regulating the supply of food, water, fuel, light, and other necessities, for maintaining the means of transit and locomotion, and for any other purposes essential to the public safety and the life of the community." There are, however, some substantial checks and limitations. Regulations must prompty be laid before Parliament and expire within a week unless each House (this being one of the occasions in which the Lords have substantial power, if 
Statutes enacted in response to past emergencies can be revived and applied to new varieties of the trouble at which they were aimed. The Public Order Act, 1936, ${ }^{21}$ for example, was inspired by the paramilitary activities of Sir Oswald Mosley's British Union of Fascists, who were trying to emulate the Brownshirts of the Nazi SA. In essence, it bans the wearing of political uniforms in public and participation in the control or management of organizations whose purpose is to usurp the functions of the police or armed forces or to promote political ends by the use or display of physical force; authorizes the police to regulate the route of public processions when they have reasonable ground to apprehend serious disorder; ${ }^{22}$ and prohibits the possession of "offensive" weapons and the practice of provocative words or behavior in public places. The Fascists ceased to be much of a problem after the outbreak of World War II, ${ }^{23}$ and the Attorney General has rarely authorized prosecutions under the Act. ${ }^{24}$ A series of I.R.A. bombings in England in the late thirties produced the Prevention of Violence (Temporary Provisions) Act, 1939, ${ }^{25}$ applicable only to persons suspected of complicity in "acts of violence designed to influence public opinion or Government policy with respect to Irish affairs." Though there might be no evidence sufficient to convict them of criminal acts, the Home Secretary was authorized to order persons of whose complicity he was "reasonably satisfied" to register with and report regularly to

they dare to exercise it) passes a resolution providing for its continuance. No regulation may provide for compulsory military or industrial service, nor make it an offense to take part in a strike or peacefully persuade other persons to do so. However, regulations issued during a dock strike in 1949 prohibited the inducement of His Majesty's military or police forces to withhold their services. See Cotter, supra note 13, at 402. On the other hand, the subjective wording of the Act seems to be intended to put beyond judicial review both the existence of an emergency and the necessity of regulations purporting to deal with it. Moreover, a provison that regulations "shall have effect as if enacted in this Act" would make it very difficult to argue that any regulation, not inconsistent with the explicit prohibitions of the statute, exceeded the parliamentary grant of authority and was thus ultra vires. See S. DE Smith, Constitutional and Administrative LAw 520-22 (2d ed. 1973); Cotter, supra note 13, at 397. Although proclamations have been made and regulations issued under the Act in about a dozen major strikes since 1920 (and British soldiers have expended many gallons of sweat on such tasks as working cargo), there appears to be no case in which a regulation has been challenged in the courts.

21. 1 Edw. 8 \& 1 Geo. 6, c. 6, as amended by the Public Order Act, 1963, c. 52.

22. The City of London was excepted from this provision because the London police already had adequate powers under the Metropolitan Police Act, 1839, 2 \& 3 Vict., c. 47. See S. DE Smrth, supra note 20 , at 502. The police have a common-law right to attend a public meeting on private premises if they reasonably believe that their presence is necessary to prevent a breach of the peace or incitement to violence. Thomas v. Sawkins, [1935] 2 K.B. 249.

23. Most of the active members of the British Union of Fascists, including Sir Oswald himself, were interned under regulations issued pursuant to the Emergency Powers (Defence) Act, 1939, 2 \& 3 Geo. 6, c. 62. See Rex v. Secretary of State for Home Affairs, ex parte Budd, [1942] 2 K.B. 14 (C.A.).

24. The Act was recently invoked when a London magistrate fined a dozen members of the Provisional Sinn Fein (the political wing of the Provisional Irish Republican Army) $£ 50$ apiece for wearing black berets at a meeting at Speakers' Corner in Hyde Park. The Times (London), Nov. 21,1974 , at 3 , col. 1 .

25. $2 \& 3$ Geo. 6 , c. 50 . 
the police and, if they were nonresidents, to order them expelled or excluded from Great Britain. The police were empowered to arrest without warrant and detain for up to seven days persons whom they "reasonably" suspected of coming under one or another of the Act's provisions.

The anti-I.R.A. Act of 1939 expired in $1955 .{ }^{26}$ But in 1973 the I.R.A. began another campaign to influence British public opinion or Government policy in its own favorite way. There were a dozen major bombings. More than twenty-five people were killed and about four hundred wounded, most of them innocent civilians-passers-by, tourists in the Tower of London, people having a pint or so in pubs frequented by soldiers. ${ }^{27}$ The campaign culminated on November 21, 1974. Satchel charges planted in a couple of pubs in Birmingham, which were crammed with teenagers, killed twenty-one people and wounded many more. ${ }^{28}$ This masterpiece of indiscriminate terror influenced public opinion and Government policy so powerfully and promptly that within the week Parliament passed the Prevention of Terrorism (Temporary Provisions) Act, 1974, replaced and expanded by a 1976 Act of the same title, ${ }^{29}$ which reenacted and expanded the expulsion and exclusion provisions of the 1939 statute, permitting the exclusion or expulsion (subject to administrative review $^{30}$ ) from Northern Ireland as well as Great Britain of noncitizens and citizens who had not resided in Great Britain for twenty years or since birth. ${ }^{31}$ This time, moreover, Parliament went farther than it had in 1939. The Act made it an offense, punishable by fine and up to five years' imprisonment, to be an active member of a "proscribed organization" (only the Irish Republican Army was proscribed by the Act itself, although the Home Secretary was empowered to add to the list any other organizations which appeared to him to be "concerned in terrorism occurring in the United Kingdom and connected with Northern Irish affairs"), to solicit finanical or other support for it, or to arrange or assist in meetings of three or more persons intended to support its activities. As in the 1936 Act, the wearing or display of any item of dress or any article indicating support of a proscribed organization was banned. Persons whom the police reasonably suspect of involvement in terrorist activity can be arrested without warrant and detained for forty-eight hours; if further

26. See 5 Halsbury's Statutes of England (2d ed. 1948), extended by 33 Halsbury's StatUTES OF ENGLAND 798-99 (2d ed. 1953).

27. The Times (London), October 7, 1974, at 2, col. 3.

28. The Times (London), November 22, 1974, at 1 , col. 1.

29. 1974 , c. $56 ; 1976$, c. 8 .

30. The Home Secretary appointed as "advisors" on exclusion appeals a Conservative life peer and a well-known Labourite barrister, who were promised round-the-clock police protection. The Times (London), December 6, 1974, at 2, col. 3.

31. The Ireland Act, 1949, 12, $13 \& 14$ Geo. 6, c. 41, recognized the independence of the Republic of Eire but provided that it should not be a "foreign country" or its citizens "aliens" for purposes of British law. Under the Representation of the People Act, 1948, 11 \& 12 Geo. 6, c. 65, Irish citizens resident in the United Kingdom can vote. 
investigation is required, the Home Secretary can extend the period for another five days. The Act does not authorize internment, but a suspected member of the I.R.A. who was deported to Northern Ireland could be interned there under the Northern Ireland (Emergency Provisions) Act, $1973^{32}$ if, but only if, he was suspected of terrorist activities there as well as in Great Britain-an anomaly that led to complaints by the Reverend Ian Paisley and other militant Ulster protestants that Ulster would become a dumping ground for British terrorists. ${ }^{33}$ As things worked out, the passage of the Act was followed (probably by mere coincidence) by a curtailment of the I.R.A.'s terrorist activities in both Great Britain and Northern Ireland, and no more than a couple of dozen exclusion orders had actually been made by the Home Secretary as of January $1975 .^{34}$ The I.R.A.'s renewal of its explosive efforts to influence British public opinion and Government policy in the direction of withdrawing Her Majesty's forces from Ulster led to the extension of the Act in December 1975, to its amendment in 1976, and to a large increase in the number of persons detained and excluded. Although the Act must be reenacted annally, it will probably remain in force so long as there is a substantial possibility of renewal of I.R.A. terrorism in Great Britain itself. There was also a strong demand for restoraiion of the death penalty for terrorist murderers. A Harris poll found that about 88 percent of the public favored the latter measure. ${ }^{35}$

Many other powers to limit the ordinary freedom of the citizen in emergencies can be found in the decisions of the courts on the common law or encapsulated in scattered Acts of Parliament. ${ }^{36}$ To select a few examples,

32. C. 53 .

33. The Times (London), November 28, 1974, at 1, col. 1.

34. See The Economist, Jan. 11, 1975, at 23. The Home Secretary was empowered by section 12 of the Act to order its extension for an additional six months after May 28, 1975, but did not do so at that time.

35. See The Economist, Dec. 6, 1975, at 9. When the Act was passed in November, 1974, the Government had some difficulty in resisting the effort of a group of about 170 Members of Parliament, including some Labour members, to authorize the death penalty for terrorist murders. The Times (London), November 28, 1974, at 1, col. 1. The I.R.A.'s renewal of bomb attacks in England in the fall of 1975 produced even stronger public and parliamentary demand for a restoration of the death penalty for terrorists. N.Y. Times, Dec. 11, 1975, at 15, col. 1. For a particularly strongly worded argument that "death is an appropriate punishment for massterrorists both in terms of natural justice and as a deterrent," see Johnson, The Resources of Civilisation, New Statesman, Oct. 31, 1975, at 531. However, Parliament again refused, although by a smaller majority, to authorize the death penalty for terrorists. See THE Economist, Dec. 13, 1975, at 27 .

Up to the middle of 1978 , more than 3,000 people had been detained under the 1974 and 1976 Acts, and 134 excluded. The workings of the Acts are described in a report of Lord Shackleton Review of the Operation of the Prevention of Terrorism (Temporary Provisions) ACTs 1974 and 1976, CMND. No. 7234, August, 1978), which made a number of suggestions for changes in the administration of the Act but concluded that it could not yet be dispensed with.

36. See generally S. DE SMITH, supra note 20, at 474-512. 
the Post Office Act, $1953^{37}$ permits the interception and seizure of material in the mails that is prejudicial to public safety or security. The informal " $D$ Notice System," administered by a "Defence, Press and Broadcasting Committee," effectively permits prior restraint of publication of matter that might have "an adverse effect on national defence or security," since disregard of a "D Notice" could invite prosecution under the Official Secrets Act, 1911, for possessing or publishing the information. ${ }^{38} \mathrm{~A}$ number of statutes require the permission of some authority for meetings in particular public places, such as Trafalgar Square. ${ }^{39}$ As a general proposition, the Englishman's freedom of expression and association rests more on official tolerance and self-restraint than on law.

Thus, British Governments have not in modern times had to resort to anything properly describable as "martial law," in the sense of a supersession of civil by military authority, or military action taken by the Government without legislative sanction. Although martial law was frequently invoked in Ireland, in British colonies, and in the Dominions (often pursuant to statute) during the eighteenth and nineteenth centuries, and the first quarter of the present century, ${ }^{40}$ Great Britain itself (that is, the British Isles other than Ireland) has had little direct experience of martial rule since Oliver Cromwell's time. Although the Crown may do what is necessary in war, and perhaps in other emergencies, without waiting for Parliament to act, ${ }^{41}$ the prevailing opinion on what has long been an essentially academic question seems to be that "martial law in the proper sense of the term probably could now only be established lawfully by, or by regulation made under, an Act of Parliament expressly authorizing the step." ${ }^{22}$ This does not, however, mean that explicit statutory authority is needed to call upon the military to assist the civil authorities.

"The common law, which governs soldiers and other citizens alike, imposes two main obligations in such cases [riot and other disturbances of the peace],

37. Post Office Act, 1953, 1 \& 2 Eliz. 2, c. 36, $\S 58$, as amended by Post Office Act, 1969, c. 48, sched. 2.

38. Official Secrets Act, 1911, $1 \& 2$ Geo. 5, c. 28, as amended by Official Secrets Act, 1920, 10 \& 11 Geo. 5, c. 75. The late S. A. de Smith, Downing Professor of the Laws of England at the University of Cambridge, was probably correct in opining that New York Times Co. v. United States, 403 U.S. 713 (1971) (the "Pentagon Papers" case), which held that the Government of the United States could not enjoin the publication of top secret documents unless it could bear the "heavy burden" of showing that publication would seriously endanger national security, would have had a different outcome in the British courts. S. DE SMITH, supra note 20, at 481 .

39. See Trafalgar Square Regulations, 1952, Stat. Inst. 1952, No. 776 (April 8, 1952). In recent years the Secretary of State for the Environment, considering the tendency of demonstrations on Irish affairs to explode into violence, has refused to sanction such assemblies in that favorite spot. See, e.g., The Times (London), October 23, 1974, at 2.

40. See generally FAIRMAN, supra note 4 , ch. IV.

41. See Burmah Oil Co. v. Lord Advocate, [1965] A.C. 75.

42. Manual of Military Law, Part I, para. 10(b) (12th ed. 1972). 
which are, first, that every citizen is bound to come to the aid of the civil power when the civil power requires his assistance to enforce law and order and, secondly, that to enforce law and order no one is allowed to use more force than is necessary." 43 Thus, to cite an example that has become rather common in the last few years, British police who do not have their own bomb squads (as is generally the case outside London) call upon the nearest military installation to defuse bombs and investigate explosions. As a matter of practice, however, the troops are not employed in aid of the civil power in situations that may entail the use of force without the sanction of the highest authorities-the Prime Minister, the Secretary of State for Defence, and the Home Secretary. ${ }^{44}$

In the light of this summary of the British legal background, let us now consider, in the context of Northern Ireland, the basic problems that have faced the legislature, the executive, and the courts. Essentially they are:

1) What were the conditions and grievances that led people in a more or less prosperous and civilized country, with a more or less democratic tradition, to resort to brutal violence, and what could have been done, or can still be done, to redress those grievances by nonviolent means?

2) Until such means are created, how can the violence be controlled with a minimum of force and a minimum of interference with normal freedom?

3) What emergency powers, such as arrest and interrogation, and search and seizure without warrant, should be given the security 'forces, police and military?

4) What limitations on the use of force should be imposed on the security forces in their efforts to maintain law and order and preserve the peace? How can the limitations be enforced?

5) What derogations from the ordinary criminal process, including internment without trial, should be permitted?

The first of these questions requires a brief description of the political situation in Northern Ireland, which shows some striking resemblances to that

43. Manual of Military Law, Part II, para. 2 (9th ed. 1969); The Bristol Riots Cases, (1832) 3 St.Tr. (N.S.) 1, 4-5. The statement in the Manual is based principally on an opinion of the Law Officers (then Rufus Isaacs and John Simon), rendered August 18, 1911, which is set out in an appendix, id. at 511 . Soldiers have the same right as other citizens to arrest without warrant, employing such force as is reasonable, persons whom they reasonably suspect of committing or attempting an "arrestable offence," defined as one for which a sentence of five years may be imposed, and to use reasonable force to prevent the commission of any crime. Criminal Law Act, 1967 , c. $58 \S \S 2,3$. The Act replaced the common-law rules on the question. See Devlin v. Armstrong, [1971] N.I. 13, 32-33 (construing the similar Criminal Law Act [Northern Ireland], 1967, c. 18). For a description of the Defence Ministry's instructions to British troops in Northern Ireland, see notes 181 and 182 infra, and accompanying text.

44. See S. DE SMITH, supram note 20 , at 513 . 
which existed in the American South before the civil rights movement of the nineteen-fifties and sixties. The major difference is that American political and legal institutions proved themselves able, however tardily, to abate the worst grievances of the minority before violence on anything approaching the Ulster scale erupted. Why did law and politics fail in Northern Ireland?

God forfend that I, an American and an American of Sassenach descent at that, should presume to explain the troubles of any part of Ireland. Accounts of the historical, social, and economic origins of the hostility between the Catholic and Protestant communities in Ulster (sometimes labelled "Republicans" and "Loyalists") have been written by intelligent people with first-hand knowledge of the province, who appear to be as objective and impartial as anyone can be in so bitter a controversy. ${ }^{45}$ Some of the causes of the hatred seem irrational to the stranger. (Of course, Ulster is by no means the only place where the lust to murder is complemented and stimulated by the human taste for irrationality.) But rational or not, what Macaulay said in 1856 is still true: "The seventeenth century has, in that unhappy country, left to the nineteenth a fatal heritage of malignant passions. No amnesty for the mutual wrongs inflicted by the Saxon defenders of Londonderry, and by the Celtic defenders of Limerick, has ever been granted from the heart by either race." 46

Nevertheless, the political causes of the trouble are plain even to an outsider. Northern Ireland was a parliamentary democracy, on paper very much like the British model, but it was also a one-party state, and that one (the Unionist Party) was kept in office by, and served the interests of, the Protestant two-thirds of the population. ${ }^{47}$ The Catholics never had a chance of exercising any degree of control over either the executive or legislative branches. Moreover, most of the judges were appointed from the ranks of the Unionist Party. In fact, there is small evidence that they were or are biased and much evidence that they were not and are not. But they were seen by the Catholics as creatures of the Protestant Establishment-even those who were Catholic were likely to be regarded as "Castle Catholics," a label roughly equivalent to "Uncle Toms"- and distrusted accordingly. ${ }^{48}$ Nothing else can explain

45. See, e.g., K. Boyle, T, Hadden, \& P. Hillyard, Law and State: The Case of Northern Ireland (1975); Palley, The Evolution, Disintegration and Possible Reconstruction of the Northern Ireland Constitution, 1 Anglo-American L. Rev. 368 (1972); Report of Tribunal of Inquiry into Violence and Civil Disturbances in Northern Ireland in 1969, Cmnd. No. 566 (Hon. Mr. Justice Scarman, Chairman 1972) [hereinafter cited as Scarman Report].

46. 2 T. Macaulay, History of England 99 (1856).

47. In some localities, of course, the Catholics are a majority, but even there gerrymandering often produced Unionist majorities in local elections. See REPORT OF THE CoMmission of INQUIRY into Disturbances in Northern Ireland, Cmnd. No. 532, para. 229 (Lord Cameron, Chairman 1969); K. Boyle, T. Hadden \& P. Hillyard, supra note 45, at 7, 10.

48. See, e.g., T. Hadden \& P. Hillyard, Justice in Northern Ireland: A Study in Social Confidence, 1 1, 30-35 (1973); Palley, supra note 45, at 398. 
adequately what is to an American lawyer the most puzzling feature of the dark and bloody tragedy-the failure of the nonviolent majority of Catholics to seek legal remedies for the discrimination they suffered in such matters as housing, public employment, and welfare. For Northern Ireland, if it differed from the rest of the United Kingdom by offering the dissidents no chance of restraining the oppression of those in power by threatening to vote them out of power, differed also in that it had something very like a constitution. "The legislative powers of the Parliament of Northern Ireland, unlike those of the Parliament of the United Kingdom, are limited by the Constitution of Northern Ireland contained in the Government of Ireland Act, 1920, as amended." 49 The Government of Northern Ireland derived all its powerslegislative, executive, and judicial-from the British Parliament's Government of Ireland Act, $1920,{ }^{50}$ which was an integral part of what was hoped at the time would be a settlement of the Irish Rebellion of 1916-21. ${ }^{51}$ Section 4 of that Act gave the Parliament of Northern Ireland "power to make laws for the peace, order, and good government of Northern Ireland," but excluded from its competence a number of matters, including war, foreign relations and treaties, and the armed forces. Any law contravening such limitations was, to the extent of the contravention, declared to be void. By the same token, section 6 denied to the Stormont Parliament the power to repeal or alter any provision of the Act or any other Act of the United Kingdom Parliament and provided that any Act of the former, so far as it was "repugnant" to an Act of the latter, or orders, rules, or regulations made pursuant thereto, should be void. Ulster was in a legal position something like that of an American state: an American lawyer begins to feel that he is treading on familiar ground. The feeling is strengthened when he reads section 5(1), which (as modified by subsequent legislation making the Act applicable only to Northern Ireland) provided a version of the first amendment and (until the repeal of the clause in 1962) of the "just compensation" clause of the fifth:

In the exercise of [its] power to make laws under this Act the Parliament of Northern Ireland shall [not] make a law so as either directly or indirectly to establish or endow any religion, or prohibit or restrict the free exercise

49. McEldowney v. Forde, [1971] A.C. 632, 658 (dissenting opinion by Lord Diplock). The Forde case is discussed in notes $216-225$ infra, and accompanying text. The observation was only dictum, for the appellant had not contended that the challenged regulation, even if authorized by statute, exceeded the power of the Northern Ireland Parliament under the Government of Ireland $\mathrm{Act}$.

50. Government of Ireland Act, 1920, 10 \& 11 Geo. 5. c. 67.

51. Other legislative implementations of the 1921 agreement with the Sinn Fein included the Irish Free State (Agreement) Act, 1922, 12 Geo. 5, c. 4, the Irish Free State Constitution Act, 1922, 13 Geo. 5, Sess. 2, c. 1, and the Irish Free State (Consequential Provisions) Act, 1922, 13 Geo. 5, Sess. 2, c. 2, the latter of which limited to Northern Ireland the application of the Government of Ireland Act, 1920. The Ireland Act, 1949, 12, 13, \& 14 Geo. 6, c. 41, recognized the complete independence of the Republic, but, of course, left Northern Ireland still a part of the United Kingdom. 
thereof, or give a preference, privilege, or advantage, or impose any disability or disadvantage, on account of religious belief or religious or ecclesiastical status, ... or take any property without compensation.

Any law made in contravention of the restrictions imposed by this subsection shall, so far as it contravenes those restrictions, be void. ${ }^{52}$

Other sections in effect authorized the courts of Northern Ireland, and the House of Lords, to determine the validity of Acts of the Parliament of Northern Ireland. Prior to the 1962 repeal of the provision requiring compensation for property taken, ${ }^{53}$ the courts were several times called upon to decide whether Acts of the Northern Ireland Parliament were "unconstitutional" takings of property without compensation. ${ }^{54}$ Indeed, the incidence of constitutional litigation under this clause seems to have led to its repeal. ${ }^{55} \mathrm{~A}$ more recent and striking example of the constitutional potentialities of the Government of Ireland Act, and also of the British Parliament's disposition to impose a strict quarantine on the introduction into any part of the United Kingdom of the doctrine of Marbury $v$. Madison, ${ }^{56}$ is Regina (Hume) $v$. Londonderry Justices, ${ }^{57}$ in which the Queen's Bench Division of the High Court of Justice in Northern Ireland set aside Hume's conviction of disobeying a regulation issued under the Civil Authorities (Special Powers) Act (Northern Ireland), $1922 .{ }^{58}$ The regulation empowered a commissioned officer of Her Majesty's forces to order the dispersal of an assembly that he suspected might lead to a breach of the peace, and the court held it invalid on the ground that it was a law "in respect of" the armed forces and thus ultra vires the Northern Ireland Parliament. The British Parliament overruled the decision within twenty-four hours by passing an Act providing (retrospectively and prospectively) that its 1920 Act should be deemed never to have had any such effect. $^{59}$

But there was nothing comparable to the American civil rights litigation of the nineteen-fifties and sixties. Cases in which actions of the Stormont Government were challenged as religious discrimination were rare. The principal examples of such litigation were two suits in the Chancery Division of the

52. Government of Ireland Act, 1920, $10 \& 11$ Geo. 5, c. 67, § 5.

53. Northern Ireland Act, 1962, 10 \& 11 Eliz. 2, c. 30, $\$ 14$.

54. E.g., Belfast Corp. v. O. D. Cars, Ltd., [1960] A.C. 490; Ulster Transp. Auth. v. James Brown \& Sons, Ltd., [1953] N.I. 79 (C.A.); see H. Calvert, Constitutional. LAw in Northern IRELAND 252-54, 271, 293-94 (1968).

55. The Lord Chancellor explained, when moving the second reading of the repealing bill in the House of Lords, that the broad interpretation to which the prohibition was susceptible placed on the Northern Ireland legislature impediments in the enactment of statutes regulating the use of property which were happily absent in Great Britain. See 236 PARL. Deb., H.L. (5th ser.) 1131 (1962).

56. 5 U.S. (1 Cranch) 137 (1803).

57. [1972] N.I. 91 (Q.B.).

58. $12 \& 13$ Geo. 5, (N.I.) c. 5. See notes $79-87$ infra, and accompanying text.

59. Northern Ireland Act, 1972, c. 10. 
High Court of Justice in Northern Ireland, brought by Catholics against local authorities, alleging discrimination in the allocation of public housing in Dungannon. ${ }^{60}$ In each case it was argued that the administrative practices of the defendant Urban and Rural District Councils in allocating public housing were unauthorized by Acts of the Parliament of Northern Ireland, but not that the discrimination was "unconstitutional" under section 5 of the Government of Ireland Act. The first case, in which the court directed the Council in future to consider applications in accordance with nondiscriminatory principles laid down by the court, could be described fairly as a victory for the Catholics. ${ }^{61}$ The second was at least not a defeat; an injunction was denied, but on grounds that would have permitted the plaintiffs to seek relief under a different procedure. ${ }^{62}$ But this hopeful beginning was not followed up. There are possible explanations besides the Catholic community's distrust of the courts. Litigation in the higher courts must be conducted by barristers, of whom there were less than a hundred in Northern Ireland, few of them eager to accept retainers which were certainly controversial and possibly perilous, and which, since the Catholics had little money, were unlikely to produce much in the way of fees. One cannot help wondering what would have happened, how many lives might have been saved, if the Irish-Americans who raised arms and money for the I.R.A. had given the money to the Campaign for Social Justice and the Northern Ireland Civil Rights Association to finance litigation.

Nevertheless, the Catholics of Northern Ireland will in all likelihood have another chance to redress their grievances with briefs instead of bombs. For if Ulster remains part of the United Kingdom, and if such a word as probable can be used about its volatile politics, it is probable that there will continue to be a reasonable facsimile of a constitution, which will at least forbid the state to practice discrimination against the religious and political minority. Only if Great Britain were to wash its hands of the mess by giving the province its independence, leaving the Protestants to write their own laws, might the Catholics be left without legal protection. Such a British abdication seems unlikely, for it would almost inevitably produce a civil war more savage than even Ulster has yet seen, a prospect that fills the Republic of Ireland with unconcealed horror. ${ }^{63}$ For that matter, the Republic has no love for the I.R.A., whose members it has often interned or prosecuted under its own

60. Campbell v. Dungannon Rural Dist. Council (Ch., March 19, 1971); McLoughlin v. Dungarinon Urban Dist. Council (Ch., April 19, 1971). The decisions are digested at 22 N. IR. L.Q. $200 \& 342$ (1971).

61. See T. Hadden \& P. Hillyard, supra note 48 , at 18.

62. Id.

63. The Irish Minister of Defence recently declared that he could not envision any circumstances in which the Republic's army would intervene in fighting in the North. N.Y. Times, Sept. 11,1975 , at 9 , col. 1 . 
Offenses against the State $\operatorname{Acts}^{64}$-and no desire to become its ally. If Northern Ireland were to be absorbed into the Republic, it would come under the latter's Constitution, which gives some protection to religous minorities ${ }^{65}$-the Catholics, of course, being the great majority in the South. But that event is very improbable; not only would it too result in civil war, but the British Government shows no sign of retreating from its reiterated position that Northern Ireland will not cease to be part of the United Kingdom without the consent of a majority of its people. ${ }^{66}$

If home rule returns to Northern Ireland, it seems clear that the British Government will insist upon constitutional protection for the minority, probably broader protection than was provided in the $1920 \mathrm{Act}$, more clearly applicable to the executive as well as to the legislature, and with somewhat clearer provisions for judicial enforcement. The Northern Ireland Constitution Act, $1973,{ }^{67}$ which repealed the quoted provisions of the $1920 \mathrm{Act}$, provides (section 17) that "any Measure [passed by the subsequently aborted Northern Ireland Assembly, which was intended to replace the Parliament of Northern

64. The Offences Against the State Act, 1939, No. 13, and Offences Against the State (Amendment) Act, 1940, No. 2, amended and extended by the Offences against the State (Amendment) Act, 1972, No. 26. The Republic's predecessor, the Irish Free State, had to resort to extraordinary measures against the I.R.A. almost as soon as it came into existence, at first by invoking martial law and then under a series of Acts of the Dáil Eireann, beginning with the Public Safety (Emergency Powers) Act, 1923, I.F.S. No. 28 and the Public Safety (Powers of Arrest and Detention) Temporary Act, 1924, I.F.S. No. 1. See The King (O'Connell) v. Military Governor, [1924] 2 I.R. 104 (K.B.); and notes 193 \& 194 infra, and accompanying text. Article 38.3(1) of the present Constitution of Ireland provides that, "Special courts may be established by law for the trial of offences in cases where it may be determined in accordance with such law that the ordinary courts are inadequate to secure the effective administration of justice, and the preservation of public peace and order." Subsection 4.(1) provides that, "Military tribunals may be established ... to deal with a state of war or armed rebellion." Under sections 5 and 6 of article 38 such special courts are exempted from the requirement of jury trial, and their decisions from challenge in the civilian courts. In 1960 The European Court of Human Rights held that the Irish Government's detention of a suspected I.R.A. terrorist under the Act did not violate the European Convention for the Protection of Human Rights and Fundamental Freedoms. Lawless Case, [1960] Y.B. Eur. Conv. on Human Rights 438, 486 (Eur. Comm. on Human Rights).

65. As a result of the fifth amendment of the Irish Constitution, enacted in 1972, that document no longer recognizes, as it did in article 44.1 of the original version of 1937, "the special position of the Holy Catholic Apostolic and Roman Church." On the other hand, article 41.3(2) prohibits divorce.

66. Section 1(2) of the Ireland Act, 1949, 12, 13, \& 14 Geo. 6, c. 41, declared that "Northern Ireland remains part of His Majesty's dominions and of the United Kingdom and it is hereby affirmed that in no event will Northern Ireland or any part thereof cease to be part of His Majesty's dominions and of the United Kingdom without the consent of the Parliament of North. ern Ireland." After the British Parliament had suspended the Stormont Parliament and empowered the British Government to exercise legislative power in Northern Ireland by Orders in Council (Northern Ireland [Temporary Provisions] Act, 1972, c. 22), the formula was changed by the Northern Ireland Constitution Act, 1973, c. 36, to provide that Northern Ireland would not cease to be part of the United Kingdom "without the consent of the majority of the people of Northern Ireland voting in a poll held for the purposes of this section."

67. C. 36 . 
Ireland], any Act of the Parliament of Northern Ireland . . . shall, to the extent that it discriminates against any person or class of persons on the ground of religious belief or political opinion, be void." 68

There is, however, a huge exception to the Act's constitutional guarantees: "No Measure, Act of the Parliament of Northern Ireland, or other instrument and no act done by any person shall be treated for the purpose of this Act as discriminating if the instrument has the effect, or, as the case may be, the act is done for the purpose, of safeguarding national security or protecting public safety or public order." ${ }^{9} 9$ Moreover, the Secretary of State's certificate that the purpose of an act was to safeguard national security is made conclusive of that fact. ${ }^{70}$

It is unlikely that the Northern Ireland Constitution Act will be the last word on the question of constitutional protection for the minority. In March 1976, the British Government dissolved the deadlocked Constitutional Convention that had been created by the Northern Ireland Act, 1974. ${ }^{71}$ For an indefinite period Ulster will continue under direct rule from London. ${ }^{72}$ Whether and when a constitution acceptable to the British Government will emerge, and what it might look like, is impossible to predict. For the foreseeable future the Catholic minority will have to make do with such protection as they are given by the Northern Ireland Constitution Act-which has yet to be tested in the courts-and whatever additional protection the Westminster Parliament may choose to give them.

The answer to problem (1) seems thus to be that there should be not only constitutional protection of the rights of the minority, but practical means of enforcing those rights-specifically, an adequate supply of lawyers able and willing to undertake the necessary litigation, and money to cover its cost. This seems obvious, even banal, but it has not been obvious in Ulster, as it was not obvious in the United States for the better part of a century after the Civil War. Something might be accomplished if barristers from other parts of the United Kingdom were allowed to appear before the courts of Northern Ireland and if public funds were made available for litigation. But so far constitutional litigation has played a minor role in the Ulster crisis. The solution

68. The only explicit provision for judicial nullification of a statute is contained in section 18 , which in effect permits the [British] Secretary of State for Northern Ireland to certify questions of the validity under section 17 of a statute or "subordinate instrument" to the Privy Council, whose decision "shall be binding in all subsequent legal proceedings." But section 19 in substance outlaws religious or political discrimination by the executive branch, apparently without regard to whether such discrimination is sanctioned by statute, and gives victims of discrimination standing to seek damages and/or injunctive relief in the courts; presumably such a proceeding could require a determination whether the statute or administrative instrument was consistent with the Act.

69. C. $36, \S 23(3)$.

70. C. $36, \S 23(4)$.

71. C. 28 . 
of problem (1) thus does not seem to be at hand in Northern Ireland. Moreover, all of the possible political solutions will probably entail continued terrorist campaigns by the Catholic or Protestant extremists, or both, and continued emergency measures by whatever government becomes responsible for the maintenance of the peace in Ulster. The extraordinary measures taken to control terrorism will continue, at least for the present, to be regulated by the British Government and acts of the British Parliament.

We must therefore turn to the other problems listed above. One possible solution to those problems, employed in many countries, is martial law. Had the Government chosen to invoke martial law, as in the earlier Irish Troubles, neither the courts of Northern Ireland nor the House of Lords would have been likely to dispute the existence of a "state of war or armed rebellion" under the old decisions of the Privy Council and the Irish courts upholding martial law in the colonies and Ireland. ${ }^{73}$ The naked statistics would be enough to satisfy any court of the existence of violence uncontrollable by the ordinary process of law enforcement. There are six counties in Northern Ireland and a total population of about one million and a half. In this little corner of the world there were, between January 1, 1971, and November 30, $1974,4,030$ bombings and 20,454 shootings. The dead numbered 1,096, including 331 policemen and soldiers, 191 terrorists, and 574 "civilians"-the last term presumably meaning people neither having nor wishing any direct involvement in the fighting. ${ }^{74}$ The slaughter has abated since the end of 1974 , but only by about one third. As of December 21, 1977, the total of dead had reached 1,800 . In 1977 , the best year since 1970,111 people were killed. ${ }^{75}$

In spite of this, neither the Government of Northern Ireland nor (after the takeover in March, 1972) the Government of the United Kingdom has used the term "martial law." The armed forces have been used, of course, and on a larger scale, since 1969, but they have exercised neither executive, legislative, nor judicial power. All of the extraordinary measures taken by the executive were based on acts, first of the Stormont Parliament, ${ }^{76}$ and after

72. N.Y. Times, March 6, 1976, at 1, col. 1. For a terse but illuminating description of the bogging down of the Constitutional Convention, see Tне Economist, Aug. 30, 1975, at 17; Sept. 13,1975 , at 35 .

73. E.g., Tilonko v. Attorney General of Natal, [1907] A.C. 93 (P.C.); Ex parte Marais, [1902] A.C. 109 (P.C.); The King v. Allen, [1921] 2 I.R. 241 (K.B.). See notes 188-192 infra, and accompanying text.

74. See Report of a CoMmittee to CONSIDER, IN THE CONTEXT OF CIVIL Liberties AND HUMAN Rights, measures to deal with terrorism in Northern IReland, CMnd. No. 5847, app. B. (Lord Gardiner, Chairman 1975) [hereinafter cited as Gardiner Report]. The total number of deaths between August 1969, and November 1974, was 1120. The Times (London), Nov, 18, 1974, at 2, col. 6. Between January 1 and August 31, 1975, about 60 Catholics and 40 Protestants were added to the list of dead, although attacks on British troops stayed at a comparatively low level. See N.Y. Times, Sept. 3, 1975, at 16, col. 1.

75. N.Y. Times, Dec. 22, 1977, \& A at 11.

76. I.e., the former Parliament of Northern Ireland, so called from its seat at Stormont Castle near Belfast. 
1972 of the Westminster Parliament, which in fact allowed almost every measure that could have been taken under martial law, save only the trial of civilians by military courts. ${ }^{77}$ The principal statute now in force is the Northern Ireland (Emergency Provisions) Act, $1973 .^{78}$

That Act can best be understood in the light of its predecessor, the Civil Authorities (Special Powers) Act (Northern Ireland), 1922, ${ }^{79}$ originally enacted by the Stormont Parliament to replace the British Restoration of Order in Ireland Act, $1920{ }^{80}$ Under the 1922 Act's authority the Government of Northern Ireland did most of the things it might have done under martial law, except try civilians in military courts. Under the Government of Ireland Act, 1920, Northern Ireland had no armed forces eo nomine, but the Royal Ulster Constabulary (a force which in 1969 numbered 3,200 men, plus a 250-man reserve) and the Ulster Special Constabulary (known as the "B Specials" and having a strength of 8,500), ${ }^{81}$ unlike the majority of British police, were armed and could be described fairly as paramilitary. The R.U.C. was 90 percent Protestant and the B Specials 100 percent. ${ }^{82}$

The Special Powers Act was cast in the most sweeping terms, with a minimum of restriction on executive discretion and procedural protection for those accused of violation, for the Protestant Parliament was not finicky about the rights of persons suspected of abetting or sympathizing with the I.R.A.

The civil authority [the Minister of Home Affairs for Northern Ireland, with nearly unlimited powers of delegation to the police] shall have power . . . to take all such steps and issue all such orders as may be necessary for preserving the peace and maintaining order, according to and in the execution of this Act and the regulations contained in the Schedule thereto, or such regulations as may be made in accordance with the provisions of this Act. ${ }^{83}$

77. There have been a few minor instances in which the military have relied on the common law. Thus, when the General Officer Commanding in Northern Ireland, acting without specific statutory authority, imposed a 35-hour curfew in the Falls Road area of Belfast on July 3, 1970, a magistrate, in an unreported decision, upheld his action as a proper exercise of the common law power to take such steps as were necessary to preserve the peace in an emergency. See $\mathrm{K}$. Boyle, T. Hadden, \& P. Hillyard, supra note 45 , at 41.

78. C. 53. It was amended in comparatively minor respects by the Northern Ireland (Emergency Provisons) (Amendment) Act, 1975, c. 62. See notes 122-180 infra, and accompanying text.

79. $12 \& 13$ Geo. 5 (N.I.), c. 5 (repealed 1973).

80. $10 \& 11$ Geo. 5, c. 31 . The Special Powers Act was reenacted annually until 1933, when it was made permanent; after the British takeover, it was repealed and replaced by the Northern Ireland (Emergency Provisions) Act, 1973, c. 53.

81. See Scarman Report, supra note 45 , at 7.

82. Id. at 17. See also Palley, supra note 45, at 399. When the British Army assumed control of the paramilitary functions of the police, in August 1969, the B Specials (particularly detested, of course; by the Catholic population) were disbanded and replaced by the Ulster Defence Regiment, a part-time paramilitary force, whose members were declared to be "members of the armed forces of the Crown" by the Ulster Defence Regiment Act, 1969, c. 65, and whose mission was to be border patrol and the guarding of key installations rather than riot control or other types of ordinary police work.

83. $12 \& 13$ Geo. 5 (N.I.), c. 5, §1(1) (repealed 1973). 
The Schedule to the Act (in substance a part of the legislation, but one which could be amended by the executive) authorized, inter alia, the imposition of curfews and the closing of "licensed premises" (that is, places where liquor was sold), the prohibition or restriction of public meetings and processions, as well as the possession of firearms, explosives, and motor vehicles; gave the Minister and the police practically unlimited power to search for and seize such contraband and to arrest and intern indefinitely persons suspected of subversive activity; required all persons to furnish information to the police upon request; prohibited interference with railways, telephones, and telegraphs; banned the spreading, orally or in writing, of statements or reports that were false, or intended to cause disaffection to His Majesty or to interfere with police operations; and empowered the civil authority to close down any newspaper. Lest these powers and prohibitions be insufficient, the Civil Authority was authorized to make further regulations for the preservation of the peace and the maintenance of order, and a catchall clause provided:

If any person does any act of such a nature as to be calculated to be prejudicial to the preservation of the peace or maintenance of order in Northern Ireland and not specifically provided for in the regulations, he shall be deemed to be guilty of an offence against the regulations. ${ }^{84}$

Offenses against the regulations were triable summarily, without a jury, by courts of two or more magistrates, and carried a maximum penalty of a twoyear imprisonment and a fine of $£ 100$. In addition, of course, the offender was subject to trial and punishment under the ordinary criminal statutes denouncing such offenses as arson and the unauthorized possession of firearms or explosives. ${ }^{85}$ Northern Ireland was lavishly supplied with such penal statutes.

Only two checks were placed on executive discretion. Regulations had to be laid before both Houses of Parliament and could in effect be annulled by either, and the first section of the Act contained a proviso that "the ordinary course of law and avocations of life and the enjoyment of property shall be interfered with as little as may be permitted by the exigencies of the steps required to be taken under this Act." ${ }^{86}$ But neither this qualification, though it seems vaguely to adumbrate the test applied by the Supreme Court of the United States in determining the constitutionality of emergency measures, ${ }^{87}$ nor Parliament's supervisory power seems to have inconvenienced the Minister or the Police. As soon as the Act was passed, the Minister began to issue

84. Civil Authorities (Special Powers) Act (Northern Ireland), 1922, c. 5, $\$$ (4).

85. Indeed, the terrorists were subjected to extra pains even when they were dealt with under the ordinary criminal law, for section 5 of the Act in its original form authorized a court convicting males of such offenses to add whipping to the statutory punishment.

86. $12 \& 13$ Geo. 5 (N.1.), c. 5, §1 (repealed 1973).

87. Scheuer v. Rhodes, 416 U.S. 232 (1974); Sterling v. Constantin, 287 U.S. 378 (1932); cf. United States v. Robel, 389 U.S. 258 (1967). See notes 257-259 infra and accompanying text. 
regulations, including one that made membership in "unlawful associations" (beginning, of course, with the I.R.A. and Sinn Fein) an offense. For nearly half a century the Act operated to the general satisfaction of the Protestant majority, and for most of that time, as will be seen, with a minimum of interference by the courts. It was supplemented not only by the penal statutes dealing with unauthorized possession of firearms, explosives, and similar paraphernalia of terrorism, ${ }^{88}$ but by a number of other acts of the Stormont Parliament aimed at both terrorists and their political supporters. ${ }^{89}$

Even this Draconian legislation did not deal effectively with violence on the scale that broke out in 1969 and has continued ever since. Indeed, the breadth of the discretion it conferred upon the executive, and the full advantage the executive took of that discretion, probably made the situation worse. A fundamental problem was that the intimidation of informers, witnesses, and (when the offense was too serious for summary trial), jurors, made it very difficult to convict terrorists by the ordinary criminal process. One bad result was resort in 1971 to internment on a large scale, with any doubt of complicity in terrorist activities resolved against the suspect. Worse, the frustrated security forces, both police and military, resorted to practices which, if not actually illegal, would not have been explicitly authorized even by the Parliament of Northern Ireland, and which, if not actually immoral, ${ }^{90}$ were not tolerable to British public opinion.

88. See, e.g., Firearms Act, (Northern Ireland), 1969, c. 12, as amended by Firearms (Amendment) Act (Northern Ireland), 1971, c. 25 (prohibiting the possession of guns or ammunition in suspicious circumstances and placing on the accused the burden of showing that possession was for a lawful purpose); Explosives Act (Northern Ireland), 1970, c. 10; Protection of the Person and Property Act (Northern Ireland), 1969, c. 29 (banning, inter alia, the making, possession, or use of Molotov cocktails unless the accused could prove a lawful purpose). A list of the penal statutes applicable to terrorist crimes at the end of 1972 is contained in REPORT of THE CommisSION TO CONSIDER LEGAL PROCEDURES TO DEAL WITH TERRORIST ACTIVITIES IN NORTHERN IRELAND, CMnd. No. 5185 (Lord Diplock, Chairman 1972) [hereinafter cited as Diplock Report].

89. These included the Emergency Powers (Northern Ireland) Act, 1926, 16 \& 17 Geo. 5, c. 8, as amended by Emergency Powers (Amendment) Act (Northern Ireland), 1964, c. 34, very similar to the British Act of 1920; Public Order Act (Northern Ireland), 1951, 15 \& 16 Geo. 6, c. 19, which empowered the Minister and the police to regulate or prohibit meetings and processions and "provocative conduct" generally; Flags and Emblems (Display) Act (Northern Ireland), 1954, 2 \& 3 Eliz. 2, c. 10, prohibiting forcible interference with the flying of the Union Jack and empowering the police to forbid the display of other flags or emblems; and Criminal Justice (Temporary Provisions) Act (Northern Ireland) 1970, c. 22, which, until its repeal by Northern Ireland (Emergency Provisions) Act, 1973, c. 53, established minimum penalties for the more serious terrorist offenses and also for certain varieties of nonviolent civil disobédience, such as sit-ins. The latter three, of course, were mainly aimed at the I.R.A. and Sinn Fein and the last also at the mainly Catholic Campaign for Social Justice.

90. A case can be made for the application of any kind and degree of force which is reasonably thought to be necessary to protect the public from terrorist violence. Jeremy Bentham, carrying utilitarian principles to a logical and arguably justifiable conclusion, wrote: "I have given the subject a very attentive consideration, and the result is that $I$ am inclined to think there are a very few cases in which for a very particular purpose, Torture might be made use of with advantage ." See Twining \& Twining, Bentham on Torture, 24 N. IR. L.Q. 305, 308 (1973). Most people believe that some wars (e.g., World War II), despite the enormous suffering which they inevi- 
These practices were the subject of two Command Papers, the Compton and Parker Reports.91 At 4:30 on the morning of August 9, 1971, British soldiers, acting under the authority of the Special Powers Act and using lists prepared by the Royal Ulster Constabulary, arrested 342 persons suspected of terrorist activity; by November another 648 had been arrested. ${ }^{92}$ By the beginning of September, 105 of the original 342 had been released, and by November 508 out of the aggregate 990 had been freed; a little less than half had been interned or were still detained pending further investigation. Since turning a man loose meant not merely that there was insufficient evidence to support a criminal charge, but that the authorities were satisfied that he was probably not a terrorist, the figures support the charge that the police relied on information that was neither correct nor current, ${ }^{93}$ and that a great many of those rounded up were seditious only in their thoughts and speech, and some of them not even that.

The errors and injustices of the internment program of 1971 obviously demonstrate that such action should be based on reliable information, and that the discretion of the security forces should be subjected to prompt (or prior) review by outside civilian authority. But they do not prove that internment is never a justifiable measure. Most of the presumptively innocent were released within a fairly short time; in a few cases, where arrests by the security forces were held to have exceeded the authority conferred upon them under the Special Powers Act, damages were awarded. ${ }^{94}$ It can plausibly be argued that the discomfort and inconvenience inflicted upon the innocent were outweighed by the danger to life, limb, and property of equally innocent people that was averted or lessened by the removal from the streets of a substantial number of genuine terrorists.

A much greater strain was placed on this Benthamite reasoning by the "interrogation in depth" to which some of those arrested were subjected and which raised in the starkest form the problem of the limits a democracy should place on the use of force and the abrogation of ordinary civil rights when it seeks to protect itself from terrorism. A former Lord Chief Justice of

tably cause, are morally justifiable, for the alternative is still greater suffering. But it is not the purpose of the present article to make moral judgments.

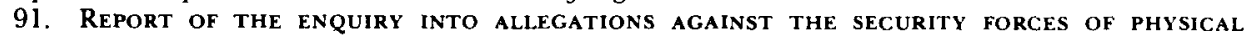
brutality in Northern Ireland arising out of events on the 9Th August, 1971, Cmnd. No. 4823 (Sir Edward Compton, Chairman 1971) (hereinafter cited as Compton Report]; REPORT OF the Committee of Privy Counsellors appointed to consider authorized procedures for the interrogation of Persons suspected of terrorism, CMnd. No. 4901 (Lord Parker of Waddington, Chairman 1972) [hereinafter cited as Parker Report].

92. Compton Report, supra note 91 , at iv, 8-9. These figures apparently do not include some 300 persons who were arrested and charged in the ordinary way with criminal offenses arising out of terrorist activity. $I d$. at $\mathbf{v}$.

93. See K. Boyle, T. Hadden \& P. Hillyard, supra note 45, at 57.

94. See note 153 infra, and accompanying text. 
Northern Ireland probably expressed the views of the larger and more civilized part of the Protestant community when he said, after reading the Compton Report:

Repugnant though it is, there is a place, compatible with the Rule of Law, for internment, as an instrument of almost last resort, which is authorized by Parliament in times of emergency. But the methods of interrogation [described in the Compton Report] are no part of statutory internment and their use serves to show how the Rule [of Law] may suffer at the hands of authority. ${ }^{95}$

The Compton Report found, in particular, that "a small number" of those arrested in the first sweep of August 9, 1971 (there were initially forty complaints, and the Committee focused on eleven cases), who were believed to possess important information about I.R.A. terrorist activities and were selected for "interrogation in depth," had been required to "stand with their arms against a wall but not in a position of stress" for periods of four and six hours. ${ }^{96}$ Their heads had been covered by black pillow slips when they were in the presence of other detainees ("hooding"); they had been subjected to continuous loud noise; and they had been placed on bread-and-water diets for unspecified periods. ${ }^{97}$ Some justifications were advanced by the security forces. ${ }^{98}$ But all of these measures, even if there was arguably some legitimate reason for them, were undoubtedly coercive and calculated to break the will of the persons to whom they were applied. The Compton Committee (which consisted of a senior civil servant, a barrister, and a physican) found that while there had been "physical ill-treatment" of the eleven detainees, the allegations of "physical brutality," which their terms of reference required them to investigate, were not supported by the evidence. ${ }^{99}$ The basis of this rather subtle distinction, which was not universally accepted, ${ }^{100}$ was set forth in these words:

95. MacDermott, The Decline of the Rule of Law, 23 N. IR. L.Q. 475 (1972).

96. Minority Report, Parker Report, Cmnd. No. 4901, para. 7(b) (Lord Gardiner 1972) [hereinafter cited as Minority Report] states that "partial records" of the Compton Committee's proceedings show that "subject to breaks for bread and water and for toilet visits, some detainees were standing continuously at the wall for periods of $6,6,7,7,7,7,7,8,9,9,9,9,9,9,9,9,9$, $9,9,9,10,10,10,11,12,13,15$, and 16 hours."

97. Compton Report, supra note 91, at 13, 15-16.

98. Id. Wall-standing was said to minimize the risk of violence against guards or other detainees when the subjects were outside their own rooms. Hooding was said to prevent detainees from identifying or being identified by each other. The noise was said to prevent the detainees from hearing or being overheard by one another. The bread and water was said to form part of "the atmosphere of discipline." The justifications for the wall-standing and bread and water do not seem to carry much conviction: Those for hooding and (to a lesser extent) noise cannot be dismissed out of hand, for suspicion by a detainee who was in fact an I.R.A. terrorist that another detainee was cooperating with the interrogators would have placed the latter and his family in deadly peril.

99. Id. at 4,71 .

100. See, e.g., Brownlie, Interrogation in Depth: The Compton and Parker Reports, 35 MoD. L. REv. 501,502 (1972). 
Where we have concluded that physical ill-treatment took place, we are not making a finding of brutality on the part of those who handled these complainants. We consider that brutality is an inhuman or savage form of cruelty, and that cruelty implies a disposition to inflict suffering, coupled with indifference to, or pleasure in, the victim's pain. ${ }^{101}$

The techniques of interrogation described in the Compton Report would, no doubt, be regarded by the secret police of Soviet Russia, Uganda, Cuba, or almost any other totalitarian regime, as practically coddling the prisoners. But regardless of whether they are properly to be termed "brutality" or merely "ill-treatment," they were clearly in violation of the "Judges' Rules" in force in England and (in a slightly stricter form) in Northern Ireland at the time. ${ }^{102} \mathrm{~A}$ statement obtained in violation of the Rules may be admitted in evidence by a judge if he finds that it was in fact voluntary. ${ }^{103}$ It was, however, clear that the courts of Northern Ireland would not have found an incriminating statement made by a defendant subjected to such treatment to be voluntary, no matter what label was attached to it. They have refused, in fact, to admit statements made in the "oppressive circumstances" of detention, even though they rejected the defendants' allegations of "physical mistreatment."104 $A$ fortiori, such confessions would have been excluded under the somewhat stricter rules applicable in an American criminal proceeding.

The fact that evidence so obtained could not be used in a criminal prosecution might not by itself have been enough to discourage the methods employed in 1971, for the purpose of the security forces was not so much to lay the groundwork for criminal convictions as to determine which suspects were sufficiently dangerous to intern and to collect information that might aid in the prevention of future violence. Knowledge of the plans for projected bombings and murders might be of only minor utility, for the I.R.A. leaders who were responsible for planning such activities could be expected to change any plans known to detainees, but every terrorist confined and every cache of

101. Compton Report, supra note 91 , at 23.

102. The Judges' Rules, a less restrictive version of the requirements imposed on American police by the Supreme Court's decision in Miranda v. Arizona, 384 U.S. 436 (1966), are based neither on legislation nor on common-law rules of evidence. They are simply directions issued by the Home Office for the guidance of policemen interrogating suspects. See Samuels, Interrogation of the Suspect, 23 N. IR. L.Q. 512 (1972).

103. E.g., Reg. v. Corr, [1968] N.I. 195 (C.A.) (affirming a conviction of a nonpolitical murder based largely on a confession made after a lengthy interrogation of a defendant in police custody, but not as a result of threats, promises, or physical coercion); Ibrahim v. The King, [1914] A.C. 599 (P.C.); see Samuels, supra note 102.

104. Reg. v. Flynn and Leonard (Belfast City Commission, May 24, 1972); The Queen v. Gargan (Belfast City Commission, May 10, 1972). The decisions are digested at 23 N. IR. L.Q. 343 (1972). See also Note, Admissibility of Confessions and the Common Law in Time of Emergency, $24 \mathrm{~N}$. IR. L.Q. 199 (1973). One difficulty, as pointed out to the writer by a person very familiar with Northern Ireland, is that the suspects in such cases are just the sort of persons whom the security forces would be tempted to ill-treat, and also just the sort of persons who would claim that they had been ill-treated even if they had not. 
arms discovered as a result of interrogation was a net gain to the police and the military and in all probability saved a number of lives. ${ }^{105}$

The next question, which the Compton Report had left unanswered, was whether the sort of "interrogation in depth" employed in 1971 was legal, or (as the question was phrased in the terms of reference of the Parker Committee) "whether, and if so in what respects, the procedures currently authorized for the interrogation of persons suspected of terrorism and for their custody while subject to interrogation require amendment."106

The authority cited for the Army's rough methods of questioning suspects was a "Joint Directive on Military Interrogation in Internal Security Operations Overseas," originally promulgated on February 17, 1965 and amended on February 10, 1967.107 The Directive, whose language suggests that lawyers had some hand in its drafting, did not sanction the practices in vogue in so many despotisms, past and present: "[A]part from legal and moral considerations, torture and physical cruelty of all kinds are professionally unrewarding since a suspect so treated may be persuaded to talk, but not to tell the truth." Moreover, "Military personnel are to acquaint themselves with the laws of the country concerned, and will not act unlawfully under any circumstances whatsoever." Finally, the rules of article 3 of the 1949 Geneva Convention Relative to the Treatment of Prisoners of War were made applicable, whether or not the local terrorism was actually covered by that Convention. ${ }^{108}$ That article, whose protections are considerably less than those provided for prisoners of war-that is, members of the armed forces of parties to the convention captured in the course of international hostilities-provides that "[p]ersons taking no active part in hostilities," including captured insurgents, "shall in all circumstances be treated humanely," and prohibits "violence to life and person, ... cruel treatment and torture" and "outrages upon personal dignity, in particular, humiliating and degrading treatment." But after all this, paragraph

105. There was a marked increase after August 9, 1971, in the quantity of machine guns, rifles, pistols, shotguns, rockets, ammunition, and explosives seized by the security forces in Northern Ireland, and also in the amount of information about the I.R.A. and its terrorist activities. See Parker Report, supra note 91, at paras. 20, 21.

106. Id. at $\mathrm{v}$.

107. The pertinent provisions of the Directive are printed in an Appendix, id. at 23. Its exact provenance is not clearly explained in either the Compton or Parker Reports, but internal and other evidence suggests that it emanated from the Ministry of Defence and was based on the experience acquired by the British Army in the liquidation of such troubled and troublesome parts of the Empire as Palestine, Malaya, Kenya, and Cyprus. See Parker Report, supra note 91, at 10-13. A gloss on the "general rules governing the custody of detainees and the processes of interrogation" was contained in a later "Note on Interrogation," which apparently also assumed the applicability of the Joint Directive to Northern Ireland, although that province is, of course, a part of the United Kingdom. The text of the Note is reproduced in Compton Report, supra note 91 , para. 46.

108. Article 3 is by its terms applicable to "an armed conflict not of an international character occurring in the territory of one of the High Contracting Parties." The violence in Northern Ireland seems sufficiently great and widespread to be described as "an armed conflict." 
8 of the Directive reminds us that England had not gained entirely by kindness and moral suasion the empire that she was relinquishing:

To obtain successful results from interrogation, the actual and instinctive resistance of the person concerned to interrogation must be overcome by permissible techniques. This will be more easily achieved by sustained interrogation in an atmosphere of rigid discipline. It may therefore be necessary for interrogation to be carried out continuously for long periods both by day and night with consequent disruption of the normal routine of living. ${ }^{109}$

The Parker Committee was of several minds on the morality of hooding, wall-standing, continuous noise, and bread and water. Lord Parker and Mr. Boyd-Carpenter were, if an Americanism may be employed, somewhat mush-mouthed. They boggled at carrying Jeremy Bentham's logic ${ }^{110}$ to its ultimate conclusion: "We do not subscribe to the principle that the end justifies the means. The means, in our view, must be such as not only comply with the Directive, but are morally acceptable, taking account of the conditions prevailing." 111 On the other hand,

So far as the moral issue is concerned, we feel that in a limited number of situations, in particular those in which guerrillas are concerned, the attitude taken up by the witnesses as set out in paragraph 8 [that 'even though innocent lives could be and had been saved by the use of the techniques described in the Compton Report, a civilized society should never use them'] is unrealistic and one that is unfair both to the State and to law-abiding citizens. $^{112}$

Thus, they concluded that "the answer to the moral question is dependent on the intensity with which those techniques are applied and on the provision of effective safeguards against excessive use." 113 Lord Gardiner was more explicit in his disapproval and, in particular, would have no part of the Compton Committee's delicate distinction between "brutality" or "cruelty" and "physical ill-treatment." ${ }^{14}$ But all three agreed that some of the treatment was illegal, if not under international law, at least under domestic lawamounting, in fact, to criminal assault. ${ }^{115}$

109. This provision of the Directive is printed in the Parker Report, supra note 1, Appendix at 24 .

110. See Twining \& Twining, supra note 90.

11. Parker Report, supra note 91, para. 27.

112. Id. para. 32.

113. Id. para. 34 .

114. Minority Report, supra note 96, para. 7(d).

115. Parker Report, supra note 91, paras. 2, 38; Minority Report, supra note 96, paras. 8, 10.

The majority, while stating unequivocally that "some if not all the techniques in question would constitute criminal assaults and might also give rise to civil proceedings under English law," refrained "from expressing any view in respect of the position in Northern Ireland, in deference to the courts there, before whom we understand proceedings which raise this issue are pending;" Lord Gardiner found nothing in the statutes of Northern Ireland or the decisions of its courts which would lead to a different opinion. Id. para. 10. Whatever doubt there may have been about the law of Northern Ireland was shortly dissipated by its courts. On February 18, 1972, a county 
Parliament presumably has power to authorize hooding, wall-standing, and the other practices described in the Compton Report, as all three members of the Parker Committee implicitly recognized. The majority thought that such techniques should only be employed with the express authority of a United Kindgom Minister; ${ }^{116}$ Lord Gardiner did not favor such legislation under any circumstances. ${ }^{117}$ The question is not open-and-shut. The interrogation techniques were shocking to humanitarians, but they were almost humane by the standards not only of totalitarian governments but by those of the terrorists themselves. ${ }^{118}$ Harsh treatment (not calculated to cause serious bodily injury) might be justified in the case of actual terrorists, or even persons who were reasonably suspected of terrorism, if it really secured intelligence that saved perfectly innocent people (including soldiers and policemen) from death or maiming. Whether it did can never, of course, be known for certain; it seems, however, intrinsically probable that the internment of real terrorists (and many of these were undoubtedly among those arrested) and the confiscation of large quantities of weapons and explosives, capable of indiscriminate and large-scale destruction, did in fact reduce the toll of life and limb. Lord Gardiner's view that "substantially as much information" might have been obtained by milder methods rested largely on his belief that in World War II:

[P]risoners and suspects were treated with kindness and courtesy and without anything which would contravene Article 17 [of the Geneva Prisoners of War Convention, which provides that "No physical or mental torture, nor any other form of coercion, may be inflicted on prisoners of war to secure from them information of any kind whatever"], that, as is now well known, it was accompanied by interrogation, the cross-referencing of information and the use of microphones and 'stool pigeons' in cells. . . . [T] There were occasions when information was wanted, and was obtained in a matter of hours, relating particularly to the course of U-boat packs or the path to be taken on the next air raid and that, even after the Germans knew of the methods and warned their men about microphones in cells and the use of 'stool pigeons,' the

judge, Roger (Rory) Conaghan (who was murdered by the I.R.A. in September 1974, probably because he was both a Catholic and a judge in whose impartiality the Catholic community trusted), awarded damages of $£ 300$ (the jurisdictional maximum) in an action for assault and battery by a plaintiff who had been arrested on August 9, 1971, against the Northern Ireland Ministry of Home Affairs and the British Ministry of Defence. Moore v. Shillington (Armagh County Court Feb. 18, 1972); see K. Boyle, T. Hadden \& P. Hillyard, supra note 45, at 135-36. By the spring of 1973 about 150 suits had been brought against the Crown based on alleged assaults by members of the security forces, most of which were settled out of court. See a statement in Parliament by the Attorney General, 855 PARL. Deb., H.C. (5th ser.) 388 (1973) (statement by Attorney General). In late 1974 the High Court in Northern Ireland awarded aggregate damages of $£ 51,000$ to four men, including two of those mentioned in the Compton Report. The Times (London), Dec. 11, 1974, at 2, col. 7.

116. Parker Report, supra note 91, para. 37.

117. Minority Report, supra note 96 , paras. $19 \& 20$.

118. The I.R.A. has regularly resorted to "kneecapping" suspected defectors and informers, and sometimes people merely of political opinion different from their own, by a bullet (or sometimes an electric drill) in the kneecap; their Protestant analogues have had no qualms about copying the practice. 
methods were still effective owing to the overwhelming desire to talk to another human being whatever the circumstances. ${ }^{119}$

But the analogy between German prisoners of war and I.R.A. terrorists seems to me doubtful. Save for some S.S. men (whose mentality did in fact closely resemble that of the "hard men" of the I.R.A.), not many of the former were really fanatical. When "kindness and courtesy" failed to get results, the Americans (and probably the British as well) were on occasion not squeamish about resorting to tougher tactics. ${ }^{120}$

But whatever the moral or utilitarian justification for very rough methods of questioning, it was plain that neither Parliament nor responsible ministers would endorse them publicly. The inclination of the average, ordinarily humanitarian, Member of Parliament (or Congressman, or voter) is to tolerate the use of such methods, but only when they are "unbeknownst" to him. Neither Parliament nor any responsible minister was prepared explicitly to authorize the system of questioning described in the Compton Report; such procedures, whether or not they were sanctioned by the Directive, and apparently that instrument itself, were abandoned in March 1972, shortly after the publication of the Parker Report, and there have been no responsible allegations that they have been employed since then. ${ }^{121}$

The upshot was another thorough examination of the problems of maintaining some sort of law and order in Northern Ireland, conducted by still another Royal Commission, this one under the chairmanship of Lord Diplock, a judge of the House of Lords. ${ }^{122}$ The Commission's task was to consider:

119. Minority Report, supra note 96, para. 14(c).

120. One instance that can be documented is the use of methods, at least as harsh as those which were the subject of the Compton and Parker Reports, to extract incriminating statements from a group of S.S. men suspected of having massacred American prisoners of war at the Belgian village of Malmédy during the Ardennes offensive of 1944. See, e.g., the Petition and Exhibits, Everett on behalf of Bersin v. Truman, 334 U.S. 824 (1948); Fairman, Some New Problems of the Constitution Following the Flag, 1 StaN. L. Rev. 587, 597-99 (1949). It is an odd fact that liberals showed very little interest in this episode, and that the only American politician who made much of a fuss about it was the late Senator Joseph R. McCarthy. See R. Rovere, Senator Joe MCCARThy 111-112 (1959). Mr. Rovere, who thinks that the charges were as baseless as most of the Senator's other allegations, seems not to have heard of the Bersin case, as perhaps McCarthy himself had not. But the affidavits and other exhibits in that record seem to have more authenticity than most of McCarthy's "evidence." Although an evenly divided Supreme Court refused to hear the petition for lack of jurisdiction, a Board of Investigation appointed by the Secretary of the Army found substantial evidence that third-degree methods had been employed. See FaIrMAN, supra note 4 , at 598 n. 37 .

121. Shortly after the publication of the Parker Report the Minister of Defence stated in the House of Commons: "When British Forces are operating in aid of the civil power, the conduct of interrogation is a matter for the civil authorities. If it should become necessary for Service personnel to carry out interrogation in order to obtain intelligence in any future military operation, the methods used would be based on the practice of the civil police in the United Kingdom. . . The proceedings will be laid down in the revised joint directive." 833 ParL. DEB. H.C. (5th ser.) $752-53$ (1972). See Boyle, The McElduff Case and the Law of Arrest Under the Special Powers Act, 23 N. IR. L.Q. 336 n. 11 (1972).

122. Diplock Report, supra note 88 . 
what arrangements for the administration of justice in Northern Ireland could be made in order to deal more effectively with terrorist organizations by bringing to book, otherwise than by internment by the executive, individuals involved in terrorist activities, particularly those who plan and direct, but do not necessarily take part in, terrorist acts; and to make recommendations. ${ }^{123}$

The Commission defined "terrorist acts" as "the use or threat of violence to achieve political ends" and " 'terrorist activities' as embracing the use or threat of violence, planning or directing or agreeing to use, and taking active steps to promote its use or to hinder the discovery or apprehension of those who have used or threatened it."124 The Diplock Report, although not unanimously praised, ${ }^{125}$ shortly led to the enactment of the Northern Ireland (Emergency Provisions) Act, 1973,126 which adopted nearly all of its recommendations. The report and the statute are precedents that cannot be ignored by lawyers and legislators in other democracies.

A basic premise of the Commission was that a trial, a judicial proceeding, as distinct from an executive decision to intern (or, to use the word preferred by the Commission and Parliament, "detain") a suspected terrorist, must meet the minimum standards prescribed by Article 6 of the European Convention for the Protection of Human Rights and Fundamental Freedoms. In essence these are: the presumption of innocence; prompt information of the nature and cause of the charge; adequate facilities for the preparation of the defense, including the right to counsel; and the right "to examine or have examined witnesses against him" and to obtain witnesses for the defense. Article 15 of the Convention permits some relaxation of these requirements "in time of war or other public emergency threatening the life of the nation . . . to the extent strictly required by the exigencies of the situation," and the Commission thought it "unquestionable" that such an emergency existed in Ulster. Nevertheless, the Commission concluded that it was preferable that no derogation from the minimum standards, however justfiable under the Convention, be permitted in a criminal trial in a court of law. Considering that the judiciary of Northern Ireland had "in general held the respect and trust of all except the extremists of both factions," and regarded it "as of paramount importance that the criminal courts of law and judges and resident magistrates who preside in them should continue to retain that respect and trust throughout the emergency and after the emergency has come to an end."127

But the Commission believed that it would be impossible to accord the minimum rights, most particularly the right to examine hostile witnesses, in

123. Id., para. 1.

124. Id., para. 3.

125. See, e.g., Twining, Emergency Powers and Criminal Process: The Diplock Report, [1973] CRIM.

L. REv. 406.

126. C. 53 . 
every case in which it might be fairly concluded, upon substantial evidence, that the public safety required the confinement of a suspected terrorist. In too many cases witnesses would stand in throroughly justified fear for their own lives and for those of their famililes if their identities were known to the accused or even to his lawyer. Given the fact that most of them lived in Catholic or Protestant ghettos, there was no way for the state to assure their protection and thus no moral justification for compelling their testimony:

$[w]$ ith increasingly rare exceptions, the only kind of case in which a conviction of a terrorist can be obtained by the ordinary processes of criminal law is one in which there is sufficient evidence against the accused from one or more of three sources: (1) oral evidence by soldiers and policemen, whose protection can be more readily ensured; (2) physical evidence, such as fingerprints; and (3) an admissible confession by the accused. ${ }^{128}$

There had in fact been many convictions of persons charged with terrorist offenses in the ordinary criminal courts, and the number was rising even as the Commission sat. ${ }^{129}$ But the number of convictions was far smaller than the number of crimes, and most of the Report's factual premises seem to me intrinsically plausible. I am inclined to question the assumption that police witnesses can be adequtely protected. ${ }^{130}$ I have more substantial reservations $^{131}$ about the assumption that there would be many cases in which a conviction of a terrorist could be obtained solely or largely on the basis of an admissible confession.

From these premises the Commissioners concluded that there was no alternative to continued internment of suspected terrorists who could notprincipally because of intimidation of witnesses-be convicted in a court of law. ${ }^{132}$ The Report recommended the retention of the safeguards, principally administrative hearings, appeals, and periodic reviews conducted by experienced lawyers, that had been required by the British Government's Detention

127. Diplock Report, supra note 88 , para. 13 .

128. Id., para. 17.

129. See 855 Parl. Deb., H.C. (5th ser.) 276 (1973).

130. Policemen and their families do not usually live in guarded barracks, and if they are safer than civilian witnesses, it is probably only because terrorists (like other criminals) believe that the police will be particularly diligent, and not particularly scrupulous, in seeing to it that copkillers are brought to book. In fact, there have been attacks on policemen and their families.

131. See notes 145-148 infra, and accompanying text.

132. Diplock Report, supra note 88, paras. 27-34. The number of persons detained (or interned) remained fairly constant between July 1, 1973 and November 30, 1974, varying from a minimum of 535 to a maximum of 669 . See Gardiner Report, supra note 74, app. F, tab. 2. Nearly 2,000 people (of whom only 107 were Protestants) were detained without trial for varying periods of time between August 9, 1971, when the policy was begun, and December 5, 1975, when it was ended and the last internees released. See N.Y. Times, Dec. 6, 1975, at 1, col. 1. Whether the Conservatives were right in their prediction that the abandonment of internment would be "dangerous for the people of Northern Ireland" remains to be seen. There has certainly been plenty of terrorism since the end of interment, but there seems to have been a decrease, not an increase. See N.Y. Times, Dec. 22, 1977, $\$ \mathrm{~A}$, at 11. 
of Terrorists (Northern Ireland) Order, 1972, ${ }^{133}$ which had replaced the more summary procedures employed under the old Special Powers Act of 1922. Whether more might have been gained by entrusting such determinations to judges who were known to and more or less trusted by the communities than would have been lost by putting the courts in the position of conducting trials which did not provide all the basic safeguards associated with criminal process is a question whose answer depends very much on the peculiar conditions in Ulster. All that can be said is that in another place and time a body like the Diplock Commission might come to a different conclusion.

The basic objective of the Commission, and of the 1973 Emergency Provisions Act, was therefore to reduce the number of persons interned by making it easier to convict terrorists by a process that did not differ too widely from an ordinary criminal trial. This did not necessitate the creation of new crimes, for what the terrorists were doing was already punishable-if it could be proved. Thus, as the Commission saw it, ${ }^{134}$ the purpose of making criminal membership in "proscribed organizations," such as the I.R.A. and the Ulster Volunteer Force (originally designated in a schedule to the statute, but subject to additions and deletions by the Secretary of State for Northern Ireland), was not to outlaw conduct which had theretofore been innocent, but to simplify proof of criminal conspiracy, "the commonest offence committed by those who plan and direct, but do not necessarily take part in terrorist acts." "Persons who join an association which advocates the unlawful use of violence by its members ... thereby become parties to an agreement for the unlawful use of violence. The mere fact of doing so makes them guilty of a wellestablished crime at common law-that of criminal conspiracy." 135

The thrust of most of the Report's other recommendations was similarly in the direction of making it easier to get convictions for acts that were already crimes. The "scheduled offences" were defined not in terms of motivationmotivation might be hard to prove, and members of terrorist groups might sometimes combine business with pleasure, having personal reasons for a

133. Stat. Inst. 1972 (N.I. 15), No. 1632 (Nov. 6, 1972).

134. Diplock Report, supra note 88, para. 21.

135. Id. From a practical standpoint, the prosecution would be saved the time and trouble of proving anew in every case the fact that the Irish Republican Army or the Ulster Freedom Fighters advocated the unlawful use of violence by their members, and freed of the risk that a slip in the presentation of the evidence of that fact, however cut and dried, might lead to reversal of a conviction. Additionally, the task of proving membership was simplified by making the accused's possession of documents concerning the organization sufficient evidence; proof that such documents were in his possession, or in premises which he occupied or controlled, would shift to him the burden of showing that he was not a member. Up to November 1974, there were only 28 prosecutions under the 1973 Act, 22 successful, in which the sole charge was membership in a proscribed organization, in large part because in most cases more serious charges could be preferred. See Gardiner Report, supra note 74, para. 67. 
murder or robbery. Instead they were defined as "those crimes which are commonly committed at the present time by members of terrorist organizations," specifically violations of statutes relating to firearms and explosives, armed robbery and assault, arson, "intimidation with intent to interfere with the course of justice, riot and similar offences under statute," and "other serious offences against person or property," such as murder. ${ }^{136}$

The most radical change recommended by the Diplock Commission and adopted by Parliament was that "scheduled offences" be made triable without a jury, by a single Judge of the High Court (for major crimes) or the County Court, with the usual rights of appeal. ${ }^{137}$ The Commission's reasons seem to me strong and even compelling. In the first place, jurors were nearly as vulnerable to intimidation as witnesses. In the second place, the selection of an unbiased jury to try a terrorist would be at least extremely difficult. Protestants were more likely to benefit from biased juries than Catholics, for there were more of them, and more of them than Catholics were able to meet Ulster's property qualification for jury service. ${ }^{138}$ But in some solidly Catholic areas, such as County Armagh, an I.R.A. man could count on treatment like that which Ku Klux Klansmen used to get from Mississippi juries. Moreover, in many areas a jury would be likely to include a few Catholics, resident in a Catholic ghetto, who could not be guaranteed security against reprisal, even if they were not prejudiced. ${ }^{139}$ In short, although it was not impossible to get convictions when there was evidence that could be presented in open court, an Ulster jury was likely to be eminently unsuitable for the fair trial of a suspected Protestant or Catholic gunman. A likely result would be an unjust acquittal or hung jury; unjust convictions were a lesser risk, but only because the trial or appellate judges could in effect take the case from the jury and order acquittal, as they sometimes did. ${ }^{140}$

Other changes, only less radical than the abolition of the right to jury trial, were proposed and enacted in the rules of evidence and the onus of proof. It was already law in Northern Ireland and the rest of the United Kingdom that one found in possession of firearms or explosives (the charges which could most often be proved by the evidence of police or military witnesses) had the

136. Diplock Report, supra note 88, para.6.

137. Id. paras. 35-41. The Director of Public Prosecutions has, however, discretion to make particular charges triable in the usual way, presumably if he finds that the case is one in which a jury can function normally. Under section 26 of the Statute as enacted, "A prosecution shall not be instituted in respect of any offence under this Act except by or with the consent of the $\mathrm{Di}$ rector of Public Prosecutions for Northern Ireland." Northern Ireland (Emergency Provisions) Act, 1973, Eliz. 2, c. 53, \$ 26, at 1591 (1973).

138. The requirement that jurors be householders had been abolished in England some years before. See T. Hadden \& P. Hillyard, supra note 48, at 58.

139. The Criminal Procedure (Majority Verdicts) Act (Northern Ireland), 1971, c. 37, permitted a verdict by 10 of 11 or 12 jurors, except in cases of murder for which the death penalty was authorized.

140. See notes 141,142 infra. 
burden of proving a lawful purpose. ${ }^{141}$ But the prosecution had still to prove the fact of "possession"-that is, not only that the lethal contraband was found in a place where the defendant could have had control of it, but also that he knew of its presence. Where, as was commonly the case, several persons occupied the same premises or vehicle, it might be hard to show beyond a reasonable doubt that any particular one was aware of the presence of a bomb or gun. ${ }^{142}$ The Commission proposed, and section 7 of the Act provides, that in such circumstances the onus of proof be shifted to all the occupants by providing that each should be deemed guilty of possession unless he proved that he neither knew nor had reason to suspect that the firearms or explosives were there, or that he was acting under duress. ${ }^{143}$

The Commission and Parliament wrestled less successfully with the specter of the Compton and Parker Reports. The Report concluded that the basic

141. Diplock Report, supra note 88, paras. 62-64. The accused's lack of a permit is evidence of unlawful purpose, but not conclusive; he may still show that he kept the weapon to avert danger that he reasonably believed to be imminent and thus had a "lawful object." Reg. v. Fegan, [1972] N.I. 80. An interesting illustration of the proposition is Reg. v. Porte (N.I.) (C.A. April 27, 1973), digested at 24 N. IR. L.Q. 423 (1973), in which the court quashed a jury's conviction of violation of the Firearms Act (Northern Ireland), 1969, c. 12, by being in possession of a pistol and ammunition without "reasonable excuse." The accused was a bread salesman, whose job took him into both Catholic and Protestant neighborhoods; Lord Chief Justice Lowry held that the jury, if properly instructed, might have found that in the circumstances he had good reason to arm himself. There is an anecdote about a citizen of Belfast who protested to a visiting journalist that the press greatly exaggerated the hazards of life in Ulster, pointing out that every day he himself went about his business in a perfectly normal way. "What's your job?" asked the newspaperman. "I'm the tailgunner on a bakery truck."

142. Paragraph 69 of the Report used as a "striking illustration" a case, Reg. v. Whelan, [1972] N.I. 153, in which the police found a revolver and ammunition concealed in a room occupied by three brothers. Each refused to take the stand and subject himself to crossexamination, but each made an unsworn statement denying any knowledge of the weapon. The jury convicted all three, but the Court of Criminal Appeal reversed: "While there was very strong evidence that somebody was guilty of an offence in connection with the gun, there was absolutely no indication of which individual was guilty and insufficient evidence on which to found an inference that all three were in possession of the gun." [1972] N.I. at 157. Cf. Reg. v. Kennedy (N.I.) (C.A. Feb. 1, 1972), digested at 23 N. IR. L.Q. 207 (1972).

143. Diplock Report, supra note 88, paras. 70-72. Section 8 of the 1975 Amending Act, supra note 78 , made the provision inapplicable to summary trials of scheduled offenses. The Commission's suggestion that the principle be applied to any person found in the company of another who was carrying arms or explosives was not followed in section 7 of the Emergency Provisions Act. The Belfast City Commission has held section 7 inapplicable to a case in which weapons were found on one of four persons in a motor vehicle, convicting that person and acquitting the others. The Queen v. Lavery, digested in 28 N. IR. L.Q., at 195 (1977). American courts have dealt with a logically similar problem in a similar way, although not in the criminal context: Where the plaintiff in a tort suit can prove that his injury must have been caused by one of two or more defendants, but cannot prove which one caused the harm-as where he is struck by a pellet fired by one of two negligent hunters, or his car is hit almost simultaneously by two negligent drivers-each defendant may be held liable unless he comes forward with evidence which exculpates him. E.g., Hadigan v. Harkins, 441 F.2d 844 (3d Cir. 1970); Dement v. Olin-Mathieson Chemical Corp., 282 F.2d 76 (5th Cir. 1960); Summers v. Tice, 33 Cal. 2d 80, 199 P.2d 1 (1948); Jackson v. Magnavox Corp., 116 N.J. Super. 1, 280 A.2d 692 (1971). Cf. Hall v. E.I. Dupont De Nemours \& Co., 345 F. Supp. 353 (E.D.N.Y. 1972). 
goal of facilitating convictions of terrorist offenses by something resembling judicial proccess required some relaxation of the "highly technical" rules of English law on the admissibility of incriminating statements made by the accused while in custody before trial. ${ }^{144}$ But it seems unlikely that anything short of the treatment described in the Compton and Parker Reports, or even rougher methods, would be likely to wring a confession out of one of the more dangerous terrorists. The Commission did not propose to sanction such methods, nor to adopt the "Draconian rule" that any admission by the accused should be admissible if the court were satisfied that it was in fact made and the circumstances did not suggest that it was false. ${ }^{145}$ But it likewise rejected the exclusionary rule prevalent in the United States: "[A court's] function is not to discipline the police force, over which it has no direct control, by the indirect method of letting a guilty man go free to commit further crimes against public order and safety." 146 The Commissioners compromised by recommending adherence to the minimum standards set by article 3 of the European Convention for the Protection of Human Rights and Fundamental Freedoms: "Any inculpatory admission made by the accused may be given in evidence unless it is proved on a balance of probabilities that it was obtained by subjecting the accused to torture or to inhuman or degrading treatment." ${ }^{147}$ Section 6 of the Act in substance followed the recommendation. Although the Commission "would not condone" the sort of interrogation in depth described in the Compton and Parker Reports, it was not clearly outlawed under its recommendation or the statute: neither of those Reports had unequivocally conceded that wall-standing, and the other practices they had found, violated the Convention. Nor did the language adopted explicitly bar confessions obtained by threats of torture, or evidence obtained from others by such treatment. Since the practices in question had in fact been abandoned and have not since been employed, it is hard to see why the Commission and Parliament thought it necessary to state so narrowly the grounds for exclusion. In fact, few, if any, of the convictions obtained in "Diplock Courts" since Parliament adopted this and most of the Commission's other recommendations in the Emergency Provisions Act of 1973 have rested on state-

144. The Northern Ireland courts had in fact excluded confessions made at detention centers, because they found that "oppressive circumstances" (as distinct from "oppressive conduct") made them involuntary. E.g., Reg. v. Flynn and Leonard (Belfast City Commission May 24, 1972) and The Queen v. Gargan (Belfast City Commission May 10, 1972), digested at 23 N. IR, L.Q. 343 (1972). By a dictum in Reg. v. Corr, [1968] N.I. 195, a non-terrorist case, Lord Chief Justice MacDermott suggested that the rule that statements should be inadmissible if obtained by "fear of prejudice or hope of advantage exercised or held out by a person in authority" [Ibrahim v. The King (1914) A.C. 599 (P.C.)] might be extended to other forms of conduct "which might be capable of eroding the will of the suspect." [1968] N.I. at 210.

145. Diplock Report, supra note 88 , paras. 86,88 .

146. Id.

147. Id. para. 89 . 
ments whose admissibility would have been questionable under the regular rules. Lord Diplock, his colleagues, and Parliament seem to have taken a position on confessions that is at least highly controversial without doing much to advanced their basic goal. ${ }^{148}$

Other changes proposed and enacted may be summarized briefly. The first relates to bail. ${ }^{149}$ In Northern Ireland the power to grant bail was confided to Resident Magistrates and Justices of the Peace, who had exercised it rather freely in terrorist cases. These officials, the Commission found, "are in the front line of danger among the judiciary."150 Several of them had been the victims of attempted shootings and bombings, some successful. ${ }^{151}$ Accordingly, the power to admit one charged with a scheduled offence to bail was restricted to Judges of the High Court (now called the Supreme Court), who were to refuse it unless satisfied that there was no risk that the accused would fail to appear for trial, or attempt to tamper with prosecution witnesses, or commit any other crime while at liberty. ${ }^{152}$ As a practical matter, very few suspected terrorists arrested for serious scheduled offences are likely to be set free unless and until they are acquitted.

The Commission recommended, and Parliament enacted (in somewhat broader form) a relaxation of the ordinary requirements for arrest without warrant, for the benefit of members of the armed forces. The law required that a policeman or soldier making such an arrest inform the suspect of the ground for arrest and tell him under which of the regulations under the old Special Powers Act authorizing such arrests he was acting. ${ }^{153}$ The Commission

148. A somewhat similar observation may be made about the Commission's proposal (adopted by section 5 of the Act) that an exception to the rule against hearsay should be made for depositions made to the police or other official investigators by a witness whose oral testimony would have been admissible, but who had died or become otherwise unreachable, as by fleeing the Province or going into hiding, before his testimony could be given at trial. Diplock Report, supra note 88 , paras. 93-100. The recommendation was inspired by a case in which a witness had been murdered on the day before he was to testify. The relaxation of the hearsay rules is certainly far less drastic than that of the rules on confessions, but it has proved unnecessary; it has apparently not been invoked in any trial of a scheduled offence under the Emergency Provisions Actperhaps because there are so few cases in which a civilian witness is willing to make his identity public at any stage of the proceedings. The provison was repealed in 1975 . See note 168 infra.

149. Id., paras. $51-57$.

150. Id., para. 52.

151. See, e.g., The Times (London), Sept. 17, 1974, at 14, col. 7.

152. Section 3 of the Emergency Provisions Act did not follow the Report's further recommendation that, even if these conditions were met, bail would be granted only if the judge found that pre-trial confinement would cause the accused "exceptional hardship," or that he had been held in custody for 90 days without being committed for trial, plus another 90 days after commitment and before trial. Section 4 of the 1975 Amending Act, supra note 78, repealed the original provision of section 3 that persons convicted of a scheduled offense should not be admitted to bail, pending appeal and gave the power of granting bail to trial judges who had adjourned trial, as well as to judges of the newly renamed Supreme Court.

153. The courts of Northern Ireland had enforced the requirement rather strictly: A soldier's failure to furnish such information on the spot made the arrest (and a subsequent detention 
considered that, while such requirements placed no undue burden on an experienced police constable making an arrest in normal circumstances, it was "preposterous" to expect a young soldier making an arrest (sometimes under a hail of stones and other missiles from residents of the quarter, or even sniper fire) in the sectarian strongholds ("No-go" areas, both Catholic and Protestant, from which the terrorists and the inhabitants did their best to exclude the security forces), where the Army had perforce taken over from the constabulary, to state precisely the ground of arrest (which might depend on the suspect's identification, which often could not be ascertained until he had been taken to battalion headquarters), and the particular Special Powers regulation (there were five distinct grounds for arrest by military personnel) under which he was acting. Section 12 of the Emergency Powers Act now provides that a soldier on duty may arrest without warrant and detain up to four hours ${ }^{154}$ a person whom he suspects of committing, having committed, or being about to commit any offense, ${ }^{155}$ and that he need state only "that he is effecting the arrest as a member of Her Majesty's forces." The provision does not seem to me to derogate seriously from the suspect's substantial rights (in American practice, an arrestee is often not informed of the charge until he reaches the police station), and it does not seem to have generated much controversy.

One of the nastiest features of the troubles in Ulster is the participation of children (some of them no more than ten or twelve years old) and adolescents in terrorist activity. The I.R.A. in particular has often recruited such youths for the dirtiest work for the reason, among others, that their injury at the hands of the troops makes good propaganda. The Commission found the Children and Young Persons Act (Northern Ireland), 1968, ${ }^{156}$ which is generically similar to American legislation, entirely inadequate for dealing with

order) unlawful and the soldier (i.e., the Government) civilly liable for false imprisonment. E.g., In re McElduff, [1972], N.I. I (Q.B.); Kelly v. Faulkner (Q.B. Jan. 11, 1973), digested at 24 N. IR. L.Q. $210(1973) ;$ In re Close [1972] N.I. 27 (Q.B.). If the detention were unlawful, the use of reasonable force to escape would not be an offense. The courts of Northern Ireland split on the effect on such cases of Parliament's prompt and retroactive overruling of the decision in Hume v. Londonderry Justices, [1972] N.I. 91 (Q.B.), that under the Government of Ireland Act an arrest by a member of the armed forces (other than one which any citizen could make, see Criminal Law Act (Northern Ireland) 1967, c. 18), was unlawful. See note 57 supra, and accompanying text. Compare The Queen v. Meehan (Belfast City Commission Jan. 26, 1973), digested at 24 N. IR. L.Q. 214 (1973), with Reg. v. Gorman (Belfast City Commission June 21, 1973). The difference of opinion, however, concerned only the intent of Parliament. Neither decision disputed the proposition that, as the latter put it, "Parliament can quite lawfully pass an Act which retrospectively converts an act innocent when done, into a crime."

154. Diplock Report, supra note 88 , para. 49 , would have permitted temporary detention only for the purpose of establishing the suspect's identity. This limitation was not included in the Act.

155. Under the Criminal Law (Northern Ireland) Act 1967, c. 18, soldiers, like civilians, could arrest without warrant persons whom they "reasonably" suspected of committing an offense punishable by five years in prison. See note 43 supra.

156. C. 34 . 
"young persons" (aged fourteen to sixteen) who, as enthusiastic auxiliaries of the terrorists, often harassed the security forces and drew them into ambushes and sometimes committed serious offenses, including murder. It recommended changes in that Act to confer on the Juvenile Court greater flexibility as to the duration and nature of their confinement. ${ }^{157}$ Clearly there ought to be, in Northern Ireland and elsewhere, something between the usual "training school" and the usual penitentiary, for youthful-but nonetheless extremely dangerous-terrorists.

With the comparatively minor exceptions noted, the recommendations of the Diplock Commission were followed by Parliament when it enacted the Northern Ireland (Emergency Provisions) Act, 1973, on July 25th of that year. But Parliament added one change that Lord Diplock and his colleagues had not recommended, or even considered. The Criminal Justice Act (Northern Ireland), $1966^{158}$ had retained the death penalty for "capital murder," although no terrorists had been executed. The death penalty for murder had been abolished in the rest of the United Kingdom. The first section of the new Act provided that no one should suffer death for murder. ${ }^{159}$ Whether the change, however humane, was wise may be doubted. Without entering into the general debate about the morality and effectiveness of capital punishment, it seems to me in at least some cases the best way of disposing of a terrorist murderer. Quite aside from its deterrent effect, it insures (as imprisonment does not) that that terrorist will not kill again. An imprisoned terrorist is simply a standing invitation to his colleagues and sympathizers to kidnap hostages to extort his release-and they might succeed. The same danger exists, of course, during the interval between arrest and execution, but that is a much shorter period, especially in the United Kingdom, where trials

157. The Commission also recommended the creation of a new "secure unit" (the existing "training schools" offered no obstacles to escape) for the confinement (for periods up to six months) of youths convicted of "riotous behaviour" and the indefinite "detention" of those convicted of more serious acts of terrorism. Diplock Report, supra note 88, paras. 101-13. Parliament was even less specific than the Commission, which would have authorized the sentencing court to order a young person convicted on indictment of a terrorist act for which an adult could have received a sentence of five years to be "detained" (which in this context means put in prison) either in the new security unit or an ordinary prison "for such period as it thinks fit." (Under the Children and Young Persons Act such "detention" was permitted only where an adult could have received fourteen years.) Section 8 of the Emergency Provisions Act permits a court to sentence a young person convicted on indictment of a scheduled offence which in the case of an adult would be good for five years to "detention for a period specified in the sentence." It does not appear from the subsequent Gardiner Report, supra note 74, paras. 112-15, that anything was done to build the new secure unit, and Ulster's prisons are more overcrowded than ever.

158. C. 20 .

159. The judge must sentence convicted murderers to life imprisonment (except for young persons detained "during pleasure") and may at the same time recommend to the Minister of Home Affairs for Northern Ireland (i.e., for the present, the British Minister for Northern Ireland) a minimum period of imprisonment prior to parole; the Minister must, in addition, "consult" the Lord Chief Justice of Northern Ireland and the trial judge (if still available) before releasing such a murderer. 
and appeals usually take much less time than they do in this country. If fear of death ever has more deterrent effect than fear of imprisonment, ${ }^{160}$ it will be in the case of terrorists, who firmly believe that when their cause triumphs they will be freed under a general amnesty. Certainly a very large majority of the British public ( 88 percent, according to a recent Harris poll) ${ }^{161}$ believe that hanging may have a salutary effect on terrorist murderers and ought to be given a try.

The crucial question about the 1973 Act is whether the results have justified the curtailment of the ordinary rights of the citizen. Neither the Diplock Commission nor anyone else thought that their legal first aid would completely stop the flow of blood in Ulster, and of course it did not. But the bleeding was stanched and perhaps reduced to a level that could be tolerated by a community as inured to violence as Ulster. The figures are to be found in the Report of the Gardiner Committee of January $1975,{ }^{162}$ whose terms of reference were generally similar to its predecessor's, plus a specific instruction "to examine the working" of the 1973 Act. There were 2,404 explosions in 1971 and 1972, which fell to 1,626 in 1973 and the first eleven months of 1974. The number of shootings for the same periods fell from 12,384 to 8,070 -in each case a reduction of about one third: deaths fell from 642 to 454. After the Act came into effect in August, 1973, the average monthly death toll dropped from twenty-six to seventeen. The trend has continued; in 1977 there were 111 deaths. ${ }^{163}$ It is, of course, impossible to say that the improvement was due to the Act, for many other factors, equally hard to measure, such as the increasing experience and efficiency of the security forces, may have played a part. There were more convictions for terrorist crimes. While the number of internees remained fairly constant between June, 1973 and November, 1974 (varying from a high of 669 to a low of 535), the total prison population tripled (from 944 to 2,848 ) between January 1, 1973 and November $30,1974 .{ }^{164}$ The Committee, summing up the arguments for and against internment, both strong, concluded that although "detention cannot remain as a long-term policy," it was best to leave to the Government the decision on timing. ${ }^{165}$ The Government's decision to end internment at the end of $1975^{166}$ may have been based not only on the political consideration that, no matter how fair the administrative safeguards and reviews of the internment procedure provided in the Act, the practice of confining suspects

160. This is a subject of much dispute. See Symposium, Statistical Evidence of the Deterrent Effect of Capital Punishment, 85 Yale L.J. 164 (1976).

161. See The Economist, Dec. 6, 1975, at 9.

162. Gardiner Report, supra note 74, app. B.

163. N.Y. Times, Dec. 22, 1977, \& A, at 11.

164. Id., app. E \& F.

165. Id., paras. 139-49.

166. See note 132 supra. 
without trial was perceived by the Catholics (and also by the Protestants, as soon as their militants began to join the Catholics in the Maze Prison) as arbitrary and unjust, but also on the fact that Diplock courts, operating under the new procedures, had managed to convict and put behind bars an increasing number of terrorists.

On the whole, the Gardiner Committee did not recommend major changes in the Act, though it stressed the obvious truths that its provisions were justified only by the emergency and that the only real solution to that emergency must be political. ${ }^{167}$ It did recommend that section 6 , dealing with the admissibility of confessions, be amended to make clear that the court, even if it found the accused's statement was not the result of "torture or . . . inhuman or degrading treatment," still retained discretion to exclude it if the judge determined that its admission "would operate unfairly against a defendant." Such unfairness might arise not only from the use of brute force, but also where a statement was obtained "in an oppressive manner" (that is, by "threats, promises, or some form of oppressive conduct," or "against the wishes of an accused person"). ${ }^{168}$ The Committee recommended that it be amended by an explicit declaration that "nothing in this section shall prevent the court, in the exercise of its discretion, from excluding or disregarding a statement to which this section relates, or any part thereof, if in the view of the court, the interests of justice so require." ${ }^{169}$ The 1975 Amending Act ${ }^{170}$ did not adopt the recommendation, except to the limited extent of making Section 6 inapplicable to summary trials for less serious offenses.

On the other hand, the Gardiner Committee did propose the creation of a few new offenses. Considering that members of the higher echelons of the terrorist "armies," like those of conventional armies, were more likely to plan operations than to carry them out in person, and the difficulty of proving criminal conspiracy, they proposed that there be added to the scheduled offences the crime of being "concerned in the commission or attempted com-

167. Gardiner Report, supra note 74, para. 21.

168. See, e.g.,. Callis v. Gunn, [1964] 1 Q.B. 495, 501; Kuruma v. The Queen, [1955] A.C. 197, 204 (P.C.). Section 6 did not in terms deprive the courts of this common law discretion, although the language of the Diplock Report certainly suggests that its intent was to make admissible any statement produced by "oppressive conduct" short of torture or inhuman or degrading treatment. In fact, the courts of Northern Ireland had not construed section 6 as requiring the admission of any confession not barred by its very narrow terms. E.g., Reg. v. Tohill (Belfast City Commission March 6, 1974). But during the Act's first 17 months there appears to have been only one case in which a statement was excluded under the terms of section 6. See K. BoyLE, T. Hadden \& P. Hillyard, supra note 45, at 102-03. The Gardiner Report also proposed repeal of the provision permitting introduction of the written depositions of witnesses who had died or could not be found, of which no use had ever been made. Such statements were subject to the infirmities of any kind of hearsay: Section 5 "contributes nothing sufficient to override the objections to its use." Gardiner Report, stupra note 74, paras. 41-44. The provision was repealed by section 7 of the 1975 Amending Act, supra note 78.

169. Id., at $46-50$.

170. Note 78 supra. 
mission of any act of terrorism or in directing, organising, training or recruiting persons for the purpose of terrorism," punishable by imprisonment for a term not exceeding fifteen years. ${ }^{171}$ Section 19 of the Act had, as earlier noted, avoided some of the difficulties of proving conspiracy by making membership in a proscribed organization itself an offense, but the maximum penalty was only five years, which the Committee evidently regarded as inadequate for the chiefs of staff of the I.R.A. and its Protestant analogues. Where the crime charged amounts to planning and ordering an assassination or bombing, it would seem that the crime of being "concerned" in it would require much the same proof that would be necessary to convict the planner and director as a principal in the murder itself. But recruitment and training not directed to the commission of any particular crime, although quite as dangerous to public safety, would presumably have been chargeable only as conspiracy. ${ }^{172}$ Section 12 of the Amending Act added to the list of offenses "solcit[ing] or invit[ing] any person to become a member of a proscribed organization, to carry out on behalf of a proscribed organization orders or directions given, or requests made, by a member of that organization." Section 15 made it an offense punishable by five years' imprisonment, to train others, or receive training, in the use of firearms or explosives, unless the accused could prove that the training was for industrial, sporting, or some other lawful purpose.

While they were at it, Lord Gardiner and his colleagues censured the news media for giving excessive coverage to the terrorists' propaganda and for sensational reporting, which gave them a "spurious glamor." The complaint was just (and has been made in this and other countries), but the Report, opining that "there can be no question of introducing censorship in a free society in time of peace," confined itself to recommending that "it be made a summary offence [i.e., one punishable by no more than six months' confinement and a moderate fine] for editors, printers and publishers of newspapers to publish

171. Id. at 74 , para. 70 .

172. Somewhat more mysterious to the stranger was the recommendation, substantially adopted by section 16 of the 1975 Amending Act, that there be added to the Act's prohibition (section 23) of publicly dressing or behaving in such a way as to arouse "reasonable apprehension" that the slogan chanter or uniform wearer is a member of a proscribed organization, the offense of "disguise": "Any person who in a public or open place or in the vicinity of a dwelling house . . wears any form of disguise shall be liable on summary conviction to imprisonment for a term not exceeding six months or to a fine not exceeding $\$ 400$ or both, provided always that it shall be a defence that there was just cause or reasonable excuse for such behavior." Id. para. 72. Would a desire to bilk one's creditors, or avoid arrest for an ordinary crime, or to engage in some illicit assignation be a defense? The Committee's only explanation was that "the wearing of disguises for the purpose of terrorism and intimidation of innocent citizens is widespread. Many of the persons wearing these disguises are not members of any proscribed organization." Perhaps they had in mind the partisans who manned roadblocks or patrolled the streets in "No-go" areas, often wearing ski-masks and the like for the benefit of television crews and news photographers. If so, the draftsmanship seems somewhat overbroad. 
anything which purports to be an advertisement for or on behalf of an illegal organisation or part of it." The recommendation was followed only to the extent that such advertising might be treated as "soliciting" or "inviting" readers to join proscribed organizations in violation of section 12 of the Amending Act, noted above. The Committee added an earnest exhortation that the Press Council "closely examine the reconciliation of the reporting of terrorist activities with the public interest," and that the B.B.C. and the Independent Broadcasting Authority "re-examine the guidance they give to programme comptrollers or companies about contact with terrorist organisations and the reporting of their views and activities." 173

The Committee not only rejected various suggestions from civil libertarians that the powers of the security forces to arrest and search be curtailed, but made recommendations, substantially followed in sections 10 and 11 of the 1975 Amending Act, that they be somewhat increased by amending section 13 of the Act to allow warrantless search for and seizure of communications equipment as well as arms, ammunition, and explosives and by amending section 16(1) to make explicit the security forces' power to stop and question for the sole purpose of establishing identity. ${ }^{174}$

Lord Gardiner's Committee considered in a gingerly way the fourth basic problem stated at the beginning of this section-the numerous and sometimes probably justified complaints that when the security forces abused their powers (especially by being too ready to shoot to kill), there was in practice little redress for the victims. The Diplock Report's only answer to the complaint was, "Unlawful abuses, by individual members of the security forces or the police, of any of the procedures which we recommend, if they should occur, would be criminal offences or civil wrongs. They can be dealt with by criminal and civil proceedings in the courts against the offenders themselves." 175 This, of course, rested on the assumption that there would be diligent investigation and prosecution of such misconduct-an assumption many people inside and outside Ulster did not share. ${ }^{176}$ There were in fact, as noted above, a number of instances in which damages were awarded for unlawful arrest or mistreatment during interrogation. ${ }^{177}$ But this did not settle the problem of criminal sanctions against individuals responsible for police and military lawlessness. As the Gardiner Report pointed out, "Contrary to the popular impression, a scheduled offence does not necessarily connote an act of terrorism," and members of the security forces could, at the discretion of the Director of Public Prosecutions for Northern Ireland, be tried by Diplock Courts for

173. Gardiner Report, supra note 74, paras. 73-76.

174. Id., paras. 85-90.

175. Diplock Report, supra note 88 , Introduction, para. 3; for statements to similar effect concerning remedies for unlawful arrest and methods of interrogation, see id. paras. 47, 77, 86-91.

176. See, e.g., Twining, supra note 125 , at 412 .

177. See note 115 supra. 
scheduled offences, such as murder, manslaughter, or assault, committed in the course of duty. ${ }^{178}$ The Gardiner Committee recommended no change in this jurisdiction, either by amending the 1973 Act to exclude the security forces from its provisions, or by amending the Army Act to make triable by court-martial murder or manslaughter allegedly committed by a soldier in the course of duty in Northern Ireland. ${ }^{179}$ It did recommend the establishment of some sort of independent agency for the investigation of complaints against the police and possibly the Army, ${ }^{180}$ but Parliament took no action to create such an agency. In a few cases, the Attorney General or Director of Public Prosecutions has in fact authorized the trial of soldiers in Diplock Courts for manslaughter, attempted murder, and causing grievous bodily harm. The two unpublished decisions I have read are paradigms of the problems that confront troops attempting to maintain order in such a place as Ulster, of the difficulty in deciding whether a soldier acted wrongfully, and of the reasons why such charges are better tried by a civilian judge than by either a local jury or a court-martial.

In each case the central issue was the reasonableness of a soldier's decision to shoot to kill or inflict serious harm. On this issue, the instructions issued to the troops were not controlling, although they represent, of course, a significant statement of what the British Government thought to be sound policy. When the British Army intervened in Ulster, the Ministry of Defence issued to every soldier serving there a "Yellow Card" containing detailed and rather complex instructions on the circumstances in which troops on duty were permitted to open fire. ${ }^{181}$ The general tenor of the instructions is to allow the use of force that might cause death or serious bodily injury only when necessary to defend the troops, or persons whom it is their duty to protect, against the same dangers. The basic rule, of course, is that no more force may be used "than the minimum necessary to enable you to carry out your duties," but some of the specific provisions were considerably more restrictive than this.

178. Gardiner Report, supra note 74, para. 62. Under the Army Act and Queen's Regulations, within the United Kingdom any offense by a soldier that affects the person or property of a civilian is to be tried in a civilian court; the jurisdiction of courts-martial is limited to the purely military offenses (such as mutiny or desertion) and those that involve only service personnel or property. But the most serious offenses, particularly murder and manslaughter, no matter who is the victim, can be tried only in a civilian court. See Manual of Military Law, Part I, c. VII (12th ed. 1972). The Supreme Court of the United States has restricted the jurisdiction of courts-martial to "service-connected" offenses, including murder and manslaughter, which have some effect on military discipline and efficiency. O'Callahan v. Parker, 395 U.S. 258 (1969); Relford v. Commandant, 401 U.S. 355 (1971).

179. Gardiner Report, supra note 74 , paras. $62,63$.

180. Id. para. 98 .

181. The Yellow Card is "Restricted" and therefore could not be furnished to a research by the Ministry. An official was, however, kind enough to call my attention to the fact that a photostatic copy had been published on page 1 of The Times of February 1, 1972, after the "Bloody Sunday" rioting in Londonderry on January 30,1972 , when thirteen persons were killed. 
Aimed fire can be opened, after due warning, "against one carrying what you can positively identify as a firearm (including bombs) but only if you have reason to think he is about to use it for offensive purposes," he refuses to halt when ordered, and there is no other way of stopping him. The soldier can fire on someone throwing a petrol bomb (that is, a Molotov cocktail), but only if the thrower's action is likely to endanger life. People attacking or destroying property, or even stealing weapons, may not be fired upon unless their action is likely to endanger life. Potentially lethal force can be used against a terrorist who is not at the moment on the attack only if he "has in your sight killed or seriously injured a member of the security forces or someone whom it is your duty to protect," and there is no other way to arrest him. In essence, the troops cannot shoot to kill to prevent crimes, or arrest the perpetrators, except where death or serious bodily injury are concerned. Only nonlethal means may be employed to protect property or to cope with less serious offenses against the person, such as hurling rocks or bottles.

Although the Yellow Card has been described as "an accurate statement of the common law rights of the armed forces," ${ }^{182}$ the restrictions it places upon the soldiery seem somewhat narrower than those of statute or common law in either Northern Ireland or the rest of the United Kingdom. ${ }^{183}$ Thus, a soldier whose use of his weapon was not sanctioned by the Yellow Card would presumably be guilty of the military offense of disobeying a lawful order, but might nonetheless have a defense against a charge of murder, manslaughter, or assault. As Lord Chief Justice Lowry put it in one of the cases mentioned, ${ }^{184}$ "the contents [of the Yellow Card] are largely dictated by policy and are intended to lay down guidelines for the security forces but . . . do not define the legal rights and obligations of the forces under statute or common law."

The two cases were also typical in that in each there was an irreconcilable conflict between the testimony of the civilian witnesses (who were Catholics)

182. See K. Boyle, T. Hadden \& P. Hillyard, supra note 45 , at 139

183. The Criminal Law Act (Northern Ireland) 1967 , c. 18, which replaced the common-law rules, permits the use of "such force as is reasonable in the circumstances in the prevention of crime, or in effecting . . . the lawful arrest of offenders or suspected offenders or of persons unlawfully at large." Where felonies, including felonies against property, were concerned, the common law applied a similar test of reasonableness. There has been much debate and exchange of polemics among American judges and lawyers on the use of deadly force in law enforcement. The common law permits the use of whatever degree of force is reasonably necessary to arrest for a felony, including felonies against property, but not misdemeanors: The American Law Institute's Model Penal Code would sanction deadly force only when the arresting officer believes that the felony itself involves the use or threatened use of such force, or that the person to be arrested will cause death or serious bodily injury if arrest is delayed. Compare, e.g., Mattis v. Schnarr, 404 F. Supp. 643 (E.D. Mo. 1975); Sauls v. Hutto, 304 F. Supp. 124 (E.D. La. 1969); Commonwealth v. Klein, 372 Mass. 823,363 N.E.2d. 1313 (1977); Schumann v. McGinn, 307 Minn. 406, 240 N.W.2d 525 (1976); Walsh v. Oehlert, 508 S.W.2d 222 (Mo. App. 1974); see Tsimbinos, The Justified Use of Deadly Force, 4 Crim. L. Bull. 3 (1968).

184. Reg. v. MacNaughton (Belfast City Commission Sept. 5, 1974). 
and the military witnesses. Somebody was lying. Both resulted in acquittals. ${ }^{185}$ Neither acquittal, it goes without saying, was well received by the Catholic community, ${ }^{186}$ just as convictions would have created indignation among the Protestants and the security forces. There is no easy solution to the problem of punishing lawless behavior by security forces trying to cope with guerrillas amid a hostile civilian population. The civilians feel themselves oppressed by a ruthless soldiery; the soldiers see no reason to expose themselves to danger in order to safeguard the lives of people who may or may not be innocent. All that can be said is that it is hard to think of anyone better fitted than civilian judges to balance the violently conflicting interests and try to find the truth.

185. In the first, The Queen v. Foxford (Belfast City Commission March 16, 1974), rev'd (C.A. June 21,1974 ), the only undisputed fact was that the accused, a corporal leading a seven-man patrol in a Catholic neighborhood shortly after midnight, had fired a shot up a dark street which killed a twelve-year old boy some 390 feet up the street. Foxford's defense was that the boy had immediately before fired a shot at him, and that he had fired to protect himself and the other members of the patrol and to prevent the commission of a crime. All the civilian witnesses swore that no shot other than Foxford's had been fired and that the boy had no weapon. All the military witnesses supported the accused's story. There was no objective circumstantial evidence one way or the other. No gun was found, but it might easily have been taken away by other persons. The dead boy's hands bore no trace of powder, but they had been washed at the hospital before the tests could be made. The trial judge, after an exhaustive analysis of the evidence, concluded that some of the civilian witnesses were more credible than the soldiers and convicted Foxford of manslaughter. But the Court of Criminal Appeal quashed the conviction, essentially on the ground that the Crown had surprised the defense by failing to call military witnesses whom it had stated it would call and then, when it finally called them in response to the defense's protests, had been allowed to cross-examine and discredit the testimony of its own witnesses. This and other irregularities in a trial "so finely balanced" had led the judge to an "unsafe and unsatisfactory verdict," on evidence which, in the eyes of the appellate court, did not prove the charge beyond a reasonable doubt.

The other case, Reg. v. MacNaughton (Belfast City Commission Sept. 5, 1974), was basically similar. Sergeant MacNaughton was charged with attempted murder and causing grievous bodily harm, and again the central issue was whether under the statutory and common law tests discussed above, he was justified in firing at the victim. MacNaughton, in charge of an eight-man patrol in a dangerous border area of Armagh, arrested a civilian, John Walsh, who was coming from the direction where an explosion, causing military casualties, had just occurred. (The court found that the accused's suspicion that Walsh was implicated in the explosion was reasonable and the arrest lawful). Walsh swore that after his arrest he had been ordered to get over a fence and shot when he complied; MacNaughton and other members of the patrol swore that Walsh had tired to escape and disregarded three commands to halt before the shot was fired. Again, somebody was lying. Lord Chief Justice Lowry, who tried the case, carefully balanced the evidence and the intrinsic probabilities. Considering that the area was one in which patrols had frequently been ambushed and that it would have been unsafe for the soldiers to leave their planned course and run after the prisoner, and finding that some of Walsh's testimony (e.g., that he had been beaten up and denied first aid after he was shot) was contradicted by objective evidence, and finding "wholly unconvincing Walsh's manner of giving evidence about I.R.A. activity in the neighborhood," concluded that the Crown has not proved beyond a reasonable doubt that the shooting was not reasonable in the circumstances. "[I]n these circumstances one does not weigh the conduct of the accused in jewellers' scales. The law does not expect serving soldiers to be supermen.

[T]hey are sometimes faced with legal difficulties to be solved in a flash which would take a trained lawyer hours to consider. The law only expects them to be reasonable men, so long as they are at the same time responsible men."

186. See K. Boyle, T. Hadden, \& P. Hillyard, supra note 45, at 138-43. 
The two trial opinions and the appellate decision in the first case left this reader with a strong impression that the charges were considered as fairly as was possible in Ulster, or in any similar place. It is virtually certain that a Catholic jury would have convicted both defendants, that a Protestant jury or a court-martial would have acquitted both, and that a mixed jury would have been a hung jury. Short of the Tribunal that we are told awaits us on the Last Day, I cannot imagine any court whose verdict would have been accepted as just by everyone in Ulster.

On the whole, however, the courts have not so far played a great role in the Ulster tragedy. British courts have, of course, no such levers of constitutional power as do the courts of the United States. What Daniel Webster said in 1819 is still broadly true: the British Parliament has "that sovereign power, called omnipotent, which does not belong to any legislature in the United States." 187 No British judge since Lord Coke has claimed the authority to strike down an Act of Parliament because it violates the common law, seen as the fundamental law of the realm. ${ }^{188}$ They placed few limits on martial law, whether authorized by statute or based on the Crown prerogative. When martial law was invoked in the colonies the Privy Council held, in cases involving both internment and military trial of civilians, that its function was only to determine whether there was in fact a state of war, insurrection, armed rebellion, or similar crisis. If there was, that was the end of the matter, for they would not durante bello go on to examine the reasonableness of the steps taken by the executive to deal with it. Lord Chancellor Halsbury explicitly rejected the United States Supreme Court's holding in Ex parte Milligan ${ }^{\mathbf{1 8 9}}$ that a civilian could not be tried by a military court when the civilian courts were open, which had been urged by one of the petitioner's counsel in the leading case. ${ }^{190}$ When the emergency was over, the court's might inquire into the propriety of what the executive had done without express legislative sanction, but they had few occasions to do so, for the legislative practice was to pass Acts of Indemnity ratifying whatever steps the executive had taken in good

187. Trustees of Dartmouth College v. Woodward, 17 U.S. (4 Wheat.) 518,559 (1819) (D. Webster, arguendo).

188. See James Bagge's Case, 77 Eng. Rep. 1271, 1277-78 (K.B. 1615). Coke, perhaps the first of judicial activists, would have turned the common law, as made by the judges (especially himself) into a constitution. If an Act of Parliament is "against Common Right and Reason, or repugnant, or impossible to be performed, the Common Law will control it and adjudge such Act to be void." Dr. Bonham's Case, 77 Eng. Rep. 646, 652 (C.P. 1610).

189. 71 U.S. (4 Wall.) 2 (1866). See note 253 infra, and accompanying text.

190. Ex parte Marais, [1902] A.C. 109, 114 (P.C.). Accord, Tilonko v. Attorney General of Natal, [1907] A.C. 93 (P.C.). The opinion in Marais apparently ended whatever vitality was still retained in England by the idea, first broached in Wolfe Tone's Case, 27 St.Tr. 613 (1798), that a civilian may not be tried by a military court where and when the King's courts are open. See C. FaIrman, supra note 4 , at 127. 
faith, including the sentences of military tribunals. ${ }^{191}$ The Irish courts adhered to the same principles. ${ }^{192}$

It is instructive to note that after Southern Ireland got its independence, and the British Army departed, there was no revolutionary reassertion of individual liberties by the Irish Government or courts. After the Anglo-Irish Peace Treaty of December 6, $1921,{ }^{193}$ the irreconcilable members of the I.R.A. continued their assassinations, arson, and bombings; the only difference was that the new Irish Government and the new Irish National Army replaced the British as targets. The Provisional Government employed the same tactics as the British. The Army established military courts to try civilians for terrorist offenses, and the Dáil Eireann, the new parliament, promptly ratified. ${ }^{194}$

191. In Tilonko v. Attorney Ceneral of Natal, [1907] A.C. 93 (P.C.), the Privy Council held that after the colonial Parliament had passed an Act of Indemnity, providing, inter alia, that "all sentences passed by any courts-martial or by any court or person administering martial law under the authority of the Governor or of the Commandant of militia in Natal, or by any military officer purporting to exercise authority in their behalf . . . are hereby confirmed and made and declared to be lawful," not even the existence of a state of war or insurrection was open: "This Board has no power to review these sentences or to inquire into the propriety or impropriety of passing such an Act of Parliament."

192. The King's Bench Division in Ireland refused to quash a death sentence imposed by a military commission (described as a "Field General Court Martial," but not constituted under the Army Act or following the rules prescribed for courts-martial) on a man convicted of possessing arms, ammunition, and an I.R.A. manual on night fighting. The King v. Allen, [1921] 2 1.R. 241, 269 (K.B.). Accord, The King (Garde) v. Strickland, [1921] 2 I.R. 317 (K.B.); The King (Ronayne and Mulcahy) v. Strickland, [1921] 2 I.R. 333 (K.B.). On similar facts the House of Lords affirmed the denial of a writ of prohibition against a military commission, although on the ground that such a writ could be addressed only to a true court, including a court-martial, and not to "a body of officers advising" the military commander. In re Clifford and O'Sullivan, [1921] 2 A.C. 570. In one case a writ of habeas corpus was granted by the Chancery Division to a man sentenced to death by a military commission, but Charles O'Connor, Master of the Rolls, although he expressed doubt about the applicability to a capital case of the decision in Ex parte Marais, [1902] A.C. 109 (P.C.), which involved only internment, that the civil courts, once satisfied that a state of war existed, could not question the propriety of the military's actions, based his decision on the fact that the Restoration of Order in Ireland Act, 1920, provided that military trials of civilians must be by court-martial, with the procedural protections prescribed by the Army Act, and his finding that the emergency had not so increased since the passage of the 1920 Act as to justify the Crown in going beyond the limits set by the Act. Egan v. Macready, [1921] I I.R. 265 (Ch.). General Macready, invoking what he called "the well known principle that in an Area where Martial Law applies Writs of Habeas Corpus do not run," refused to release Egan; the Judge threatened to commit the General for contempt; the General threatened to arrest the Judge. The British Government ended the unseemly squabble by ordering Macready to obey the court's decision, which was not appealed. See Osborough, Law In Ireland 1916-1926, 23 N. IR. L.Q. 48, 65 (1972).

193. The British Parliament ratified the Treaty by the Irish Free State (Agreement) Act, 1922, 12 Geo. 5, c. 4, and the Government by Order in Council transferred to the Provisional Government of the Irish Free State all civil powers. The Irish Free State Constitution Act 1922, 13 Geo. 5, sess. 2, c. 1, gave the Free State what amounted to Dominion status.

194. The civil courts became courts of the Irish Free State. In the famous case of Erskine Childers, a capital case, Charles O'Connor denied a writ of habeas corpus, distinguishing his own opinion in Egan v. Macready, [1921] 1 I.R. 265 (Ch.), on the ground that the Restoration of Order in Ireland Act, 1920, 10 \& 11 Geo. 5, c. 31, applied only to the British Army. With some indignation he rejected the argument that no "state of war" existed, for the I.R.A. had recently 
Although the British courts cannot place constitutional limits on the supremacy of Parliament, they are by no means without power, if they choose to use it, to curb the actions of the executive in emergencies. They have as much power as American courts to interpret the acts of the legislature. They can hold that what the Government has done under an act of Parliament is ultra vires the act and unlawful. Parliament can, of course, amend the act to overrule the court's construction, as it did when the High Court of Justice in Northern Ireland held that under the old Government of Ireland Act, 1920, the Stormont Parliament had no power to authorize arrests by the armed forces. ${ }^{195}$ Still, there may be times when Parliament is unwilling to authorize explicitly what it is willing to tolerate or ignore, and the courts can force Parliament into that difficult choice.

The House of Lords, the Privy Council, and the lower courts have devised a number of formulae which they can invoke, if so inclined, to resolve an ambiguity in an act of the legislature against the executive, or to find an abuse of discretionary powers, when the executive's action is challenged by one of the ancient writs of habeas corpus, certiorari, mandamus, or prohibition. The apparent differences in some of the verbal formulae-they are hardly definite enough to be described as "canons of construction"-often seem to represent little more than the particular judges' choice of pejorative language to express the same idea. ${ }^{196}$ There are a great many dicta to the effect that an action taken in "bad faith" would necessarily be ultra vires: ' $^{197}$ but there appears to be no case in which an exercise of statutory authority has been invalidated be-

\footnotetext{
blown up the Four Courts in Dublin: "I am sitting here in this temporary makeshift for a Court of Justice. ... If this is not a state of war, I should like to know what is." Seldom has a court been in a better position to take judicial notice of a fact. The King (Childers) v. Adjutant General of the Provisional Forces, [1923] I I.R. 5 (Ch.), accord, The King (Johnstone) v. O'Sullivan [1923] 2 I.R. 13 (K.B.Div.), aff'd, [1923] 2 I.R. 17 (C.A.). Not until the end of July 1923 did the Court of Appeal in the Irish Free State, finding that the disturbances were no longer on a scale large enough to be described as "war or armed rebellion," order the release of an internee. The King (O'Brien) v. The Military Governor of the Military Internment Camp, [1924] l I.R. 32. Since then the Irish Government, like the British, has dealt with the I.R.A. under a series of statutes. See The King (O'Connell) v. Military Governor of Hare Park Camp, [1924] 2 I.R. 104 (K.B.); note 64 supra.

195. See notes 57-59 supra, and accompanying text.

196. "I am not sure myself whether the permissible grounds of attack cannot be defined under a single head. It has been perhaps a little bit confusing to find a series of grounds set out. Bad faith, dishonesty-those of course stand by themselves-unreasonableness, attention given to extraneous circumstances, disregard of public policy and things like that have all been referred to ... as being matters which are relevant to the question. If they cannot all be confined under one head, they at any rate, I think, overlap to a very great extent." Associated Provincial Picture Houses, Ltd. v. Wednesbury Corp., [1948] l K.B. 223, 229 (C.A.) (Lord Green, Master of the Rolls). The court held, however, that a local authority did not exceed its statutory power to license Sunday movies, "subject to such conditions as the authority think fit to impose," by imposing a condition that children under 15 not be admitted. See generally S. DE SMITH, supra note 5, at 246-311.
}

197. See, e.g., Attorney General for Canada v. Hallet \& Carey, Lid., [1952] A.C. 427, 444-45; Liversidge v. Anderson, [1942] A.C. 206, 224. 
cause the executive was shown to have been motivated by dishonesty, malice, or any other variety of bad faith. ${ }^{198} \mathrm{~A}$ closely related concept, and one of more potential significance, is that an action may be challenged on the ground that it is clearly for an improper purpose, one not intended by Parliament; ${ }^{199}$ what appears to be the same idea is expressed in other dicta (and a few holdings) that the challenged action must be "capable of being related" to a purpose of the statute in order to be intra vires. ${ }^{200}$ It is also said that an exercise of discretion may be invalid if it can be shown that it was based on irrelevant factors, or failure to consider matters that Parliament explicitly or implicitly intended to be taken into account. ${ }^{201}$ There are numerous judicial declarations that discretion under a statute must be exercised "fairly" and "reasonably," though the judges have not done much to define these terms. ${ }^{202}$ There are even statements (mostly in dissenting opinions) echoing American constitutional holdings ${ }^{\mathbf{2 0 3}}$ that a regulation under an Act may be void for vagueness. ${ }^{204}$

It has also been said that "there is a well-known general principle that statutes which encroach upon the rights of the subject, whether as regards person or property, are subject to a 'strict construction.'"205 'The idea found

198. "Mala fides is a phrase often used in relation to the exercise of statutory powers. It has never been precisely defined as its effects have happily remained mainly in the region of hypothetical cases." Smith v. East Elloe Rural District Council, [1956] A.C. 736, 770 (Lord Somervell).

199. See Attorney General for Canada v. Hallet \& Carety, Ltd., [1952] A.C. 427, 444-45.

200. Id. at 458; Padfield v. Minister of Agriculture, Fisheries and Food, [1968] A.C. 997, 1030, 1054. In The King (Zadig) v. Halliday, [1917] A.C. 260, 272-273, Lord Atkinson said that "if on the face of a regulation it enjoined or required something to be done which could not in any reasonable way aid in securing the public safety or the defence of the realm it would ... be ultra vires and void," but found the principle inapplicable in the case before him, which involved the internment of a naturalized British subject. A few World War I decisions held ultra vires regulations restricting the use of property, when the judges found that the restrictions, on their faces, could not be justified as tending to promote public safety or the defense of the realm. E.g., Chester v. Bateson, [1920] 1 K.B. 829; Newcastle Breweries, Ltd. v. The King, [1920] 1 K.B. 854; $c f$. DeKeyser's Royal Hotel v. The King, [1920] A.C. 508, which held that the Crown's prerogative in time of war did not extend to taking possession of property for administrative use, and that Acts of Parliament required the payment of compensation.

201. Padfield v. Minister of Agriculture, Fisheries and Food, [1968] A.C. 997, 1062; see S. DE SMITH, supra note 5 at 228-29.

202. S. DE SMITH, supra note 5, at 303-05; see Re W (an Infant), [1971] A.C. 682, 700.

203. E.g., Jordan v. DeGeorge, 341 U.S. 223, $231-32$ (1951).

204. See, e.g., Liversidge v. Anderson, [1942] A.C. 206, 225, 243 (dissent by Lord Atkin); Forde v. McEldowney, [1970] N.I. 11, 23 (dissent by Lord Chief MacDermott); McEldowney v. Forde, [1971] A.C. 632, 653-54 (dissent by Lord Pearce) ("A man must not be put in peril on an ambiguity under the criminal law").

205. Attorney General for Canada v. Hallet \& Carey, Ltd., [1952] A.C. at 458. But, despite this dictum, the Privy Council, reversing the Supreme Court of Canada, unanimously held that Canada's National Emergency Transitional Powers Act, 1945, c. 25 (which empowered the executive to make such orders as it might "deem necessary or advisable" for a list of very broadly worded purposes) was not so "inconclusive or ambiguous" as to justify the invocation of the principle, and that an Order which in effect confiscated profits made by trading in grain futures was intra vires the Act. 
its most eloquent expression in two famous dissents, more often quoted than followed, in wartime internment cases. In the first, The King (Zadig) v. Halliday, ${ }^{206}$ Lord Shaw of Dumferline refused to find in the language of the Defence of the Realm Consolidation Act, 1914, granting to His Majesty in Council "power during the continuance of the present war to issue regulations for securing the public safety and the defence of the realm," a Parliamentary intent to repeal pro tanto the Habeas Corpus Acts, and even Magna Carta, by authorizing the imprisonment of subjects without charges or trial of actual wrongdoing. "It is the right of personal freedom in this country which is in debate; and I for one should be very slow to believe, except it was done by express legislation, that the policy of centuries has been suddenly reversed." ${ }^{207}$ In the World War II case, Liversidge v. Anderson, ${ }^{208}$ Lord Atkin dissented on generally similar groups, and with equal eloquence, emphasizng that "in English law every imprisonment is prima facie unlawful, unless ordered by a judge."209

But in England, as in the United States, it is more instructive to look at what the courts do than at what they say; in England, as in the United States, they have not been disposed straitly to confine the powers granted the executive by statute in what they perceive as a real emergency. In Zadig four of their Lordships held intra vires the Defence of the Realm Consolidation Act, 1914, a Regulation authorizing internment of British subjects. Although the Act did not expressly grant any such power, none of the four hesitated to imply such an intent-and in fact Parliament did nothing to change the judges' reading of its intention. Lord Dunedin, although conceding that the power was "drastic and might be abused," said simply that "the fault, if fault there be, lies in the fact that the British Constitution has entrusted to the two Houses of Parliament, subject to the assent of the King, an absolute power untrammelled by any written instrument obedience to which may be compelled by some judicial body." ${ }^{10}$ In World War II, when the Emergency Powers (Defence) Act, 1939, explicitly authorized Defence Regulations to provide

\footnotetext{
206. [1917] A.C. 260.

207. [1917] A.C. at 294.

208. [1942] A.C. 206.
}

209. [1942] A.C. at 245. Fifteen years later, at a time when no particular crisis confronted Britain, Sir Leslie Scarman (now a Lord Justice of Appeal), argued that Lord Atkin's opinion "although a dissenting one, represents the law of England." Kuchenmeister v. Home Office, [1958] 1 Q.B. 496, 504. Whether or not the court accepted his statement, it found that the immigration authorities had abused their discretion (although neither negligently nor in bad faith) under the Aliens Order, 1953, Stat. Inst. 1953, No. 1671, art. 2(1)(b), (2) (April 1, 1954), when they refused to permit his client, a German national who had been deported in 1948, to cross a strip of land, separating two parts of a London airport, in order to make a connection between a flight from Amsterdam and one to Dublin. The court awarded him punitive damages for false imprisonment, stressing that "the very precious right of liberty . . is one which must be protected." [1958] l Q.B. at 513.

210. [1917] A.C. $260,270-71$. 
for internment, they construed equally broadly a Defence Regulation which, in language less sweeping than the Act's, required that the Home Secretary have "reasonable cause to believe [the internee] to be of hostile origin or associations ... . and that by reason thereof it is necessary to exercise control over him" [italics added]. But four of the five judges held that the Home Secretary's ipse dixit, a copy of his Order reciting that "I have reasonable cause to believe ... Robert Liversidge to be a person of hostile associations and that by reason thereof it is necessary to exercise control over him," was in itself a sufficient defense; the plaintiff was not entitled to demand, or the court to examine, the defendant's grounds for his belief. The majority in effect read the Regulation as requiring only that the Home Secretary believe in good faith that he had reasonable cause. ${ }^{211}$ The presumption against constructions that encroach upon personal freedom was subjected to an important qualification:

[I]n a time of emergency when the life of the whole nation is at stake it may well be that a regulation for the defence of the realm may quite properly have a meaning which because of its drastic invasion of the liberty of the subject the courts would be slow to attribute to a peacetime measure. ${ }^{212}$

These cases were wartime cases; the German armies were at the gates of Moscow when Liversidge was decided, and the Luftwaffe's bombs had killed more Londoners than the I.R.A.'s had. It is probable that in some cases during the two wars internment orders were based on secret intelligence, and in such cases an ordinary criminal trial by jury would have presented obvious difficulties. The extent of the Crown's privilege to withhold classified information from the courts is not at all clear. ${ }^{213}$ In such cases internment might be justified, but it is hard to see why-at least in most such cases-the judges could not be trusted with such information in camera, at least in sanitized form, to see if there was a reasonable basis for the internment order. Moreover, the reasons that make the normal criminal process an infirm and uncertain device for the control of dangerous people in Ulster did not exist in England in 1917 or 1941. In particular, there was no problem of intimidation of witnesses or jurors.

211. See, e.g., Liversidge v. Anderson, [1942] A.C. 206, 224 (Viscount Maugham).

212. [1942] A.C. at 251 (Lord MacMillan concurring). In a case decided a few years after the war, Lord Radcliffe, refusing to follow Liversidge, observed that "it would be a very unfortunate thing if the decision in Liversidge's case came to be regarded as laying down any general rule as to the construction of such phrases when they appear in statutory enactments." Nakkuda Ali v. M. F. De S. Jayaratne, [1951] A.C. 66, 76 (P.C.).

213. The broad privilege accorded to military and diplomatic secrets by Duncan v. Cammell, Laird \& Co., [1942] A.C. 624 was considerably modified by Conway y. Rimmer, [1968] A.C. 910. See S. DE SMITH, supra note 5, at 291-92. In the United States the rule in criminal prosecutions is that the Government must either produce any relevant material in its possession or drop the charges. United States v. Beekman, 155 F.2d 580 (2d Cir. 1946); United States v. Andolschek, 142 F.2d 503 (2d Cir. 1944). Cf. United States v. Gagnon, 21 C.M.A. 158 (1972). 
Though the crisis in Northern Ireland, even after 1969, was hardly as great as the two World Wars, the courts were equally tolerant of the actions of the authorities under the old Special Powers Act. In the first of the few tests of the legality of such actions, Rex (O'Hanlon) $v$. Governor of Belfast Prison, ${ }^{214}$ the court denied habeas corpus to O'Hanlon (nine times the Irish chess champion), who had been interned under a regulation authorizing the Northern Ireland Minister for Home Affairs to intern any "person whose behaviour is of such a nature as to give reasonable grounds for suspecting that . . he is a threat to public order." ${ }^{215}$ McEldowney $v$. Forde, ${ }^{216}$ the most recent decision of the House of Lords on the extent of the executive's powers under emergency legislation and the extent of judicial review of the exercise of such powers, and the most important such decision since Liversidge, also arose under the Special Powers Act and also gave the widest latitude to the authoritiesalthough this time there were strong dissents by two of the five judges in the House of Lords. In March 1967, the Stormont Minister of Home Affairs went beyond anything yet done, even in Ulster, when he added to the list of "unlawful associations," membership in which was punishable by fine and imprisonment, "the organizations at the date of this regulation or at any time thereafter describing themselves as 'republican clubs' or any like organization howsoever described."217 On the face of the Regulation, the Minister could have clapped into jail a visiting American adherent of the Grand Old Party. Forde, a District Inspector of the R.U.C., brought a complaint against McEldowney. The magistrates who tried the case found (there was no dispute on the facts, for it was a test case) that McEldowney was a member of the Slaughtneil Republican Club; that there was no evidence that he or the Club was a threat to peace or law and order; and that, so far as the police were aware, there was

214. 56 Ir. L.T.R. 170 (K.B. 1922).

215. Despite the objective test apparently imposed by the Regulation, the court, anticipating Liversidge, held that the internment order was adequately supported by an affidavit of an Inspector-General of the Royal Ulster Constabulary that the Police had (undisclosed) information tending to show that O'Hanlon was a member of an unlawful association and that "he had acted, was acting, and was about to act in a manner prejudicial to the preservation of the peace and maintenance of order in Northern Ireland," and stating further that "it would be . . dangerous to the lives of others, particularly those who have supplied information to the police authorities, to disclose the information. . . It cannot be thought that its disclosure to the judges themselves would have created such a danger. But the court did not suggest that the evidence might be examined in camera: "We have nothing to do with the consideration of the evidence." 56 Ir. L.T.R. at 172. The decision was not appealed, and the test of reasonableness was shortly deleted from the Regulation, by authorizing the Minister to intern any person "whom he suspects of ... being a threat to public order," See H. Calvert, Constitutional Law in Northern Ireland 382 (1968):

216. [1971] A.C. 632 .

217. "Republican clubs" seem to be the political branch of the "official" I.R.A., a faction which has not joined the campaign of terrorism carried on by the rival "Provisional" I.R.A., and which, in fact, has engaged in hostilities against the Provisionals. See The Economist, April 16, 1977, at 16. The ban on republican clubs was lifted in 1973, after the British takeover. See T. Hadden \& P. Hillyard, supra note 48 , at 12 n.7. 
nothing seditious about it or its members. They dismissed the complaint. ${ }^{218}$ The Court of Appeal in Northern Ireland, Lord Chief Justice MacDermott dissenting, held that the Special Powers Act permitted even this proscription. ${ }^{219}$ But the Special Powers Act, though hardly narrowly drawn, did seem to place certain limits on executive discretion. Under section $1(1)$, the civil authority was empowered "to . . . issue all such orders as may be necessary for preserving the peace and maintaining order," objective language which might be read to mean that an order was ultra vires if on its face it had no tendency to preserve peace and order. The same subsection, moreover, ended with a proviso "that the ordinary course of law and avocations of life and the enjoyment of property shall be interfered with as little as may be permitted by the exigencies of the steps required to be taken under this Act." Similarly, section 1(3), under which the Minister had acted, gave him power "to make regulations ... for making further provision for the preservation of the peace and the maintenance of order." Nevertheless, the majority of the Court of Appeal found that the Regulation was not made in bad faith and was "capable" of being related to the preservation of the peace and the maintenance of law and order; "it is not for the court to take into its own hands the functions entrusted by Parliament to a Minister of the Crown."220 Lord Chief Justice MacDermott, believing that the Minister's powers were limited by the words "as may be necessary for preserving the peace and maintaining order," dissented and even used language which, for a British judge, came fairly close to what an American court would have said:

In my view, the 1967 regulation is far too vague and wide to come within even the extensive powers of section 1. In the absence of anything to show the contrary, it cannot be regarded as a step necessary or even likely to preserve the peace or maintain law and order. It is not . . . "capable of being related" to these prescribed purposes. ${ }^{221}$

The majority and dissenting opinions in the House of Lords followed generally similar lines. All of the judges agreed that the Minister had not acted in bad faith. Lord Hodson thought the Regulation was not so "vague and arbitrary as to be wholly unreasonable"; the word "republican" was "capable" of describing a club which the Minister might believe (apparently without regard

218. The Magistrates construed the Regulation as intended to cover only "republican clubs"; with unlawful objects and accordingly dismissed the complaint. Their construction was not adopted by the appellate judges, including the dissenters, for British judges are less willing to twist the meaning of a regulation to save it from being ultra vires a statute than American judges are to rewrite a statute to save it from unconstitutionality.

219. There was no contention that the Special Powers Act, if interpreted to confer such power, was itself ultra vires the Government of Ireland Act, probably because it would have been hard to argue that there was religious discrimination; practically all of the members of republican clubs were, of course, Catholics, but their purpose was political.

220. Forde v. McEldowney, [1970] N.1. 11, 27-38.

221. [1970] N.I. at 23. 
to the reasonableness of his belief) to be subversive. Lord Guest, remarking, "I do not know what significance the word 'republican' has in Northern Ireland," also found "capability." ${ }^{222}$ Lord Pearson made a majority. He acknowledged that a Regulation declaring chess clubs (perhaps an echo of O'Hanlon's case) to be unlawful might be ultra vires, but republican clubs were a very different matter. ${ }^{223}$ It may also be remarked that in 1967 the serious violence in Ulster had not begun. Obviously the banning of republican clubs did nothing to prevent, and may well have done something to encourage, a rising militancy among the Catholics. Indeed, the decision in McEldowney may itself be one of the reasons why the Catholic community never followed up its initial, at least partly successful, efforts to seek redress in the courts.

Lords Pearce and Diplock could not see any likelihood that the prohibition could serve the purposes for which Parliament had given the Minister his powers. As the latter put it:

What degree of likelihood is sufficient and to what extent the likely effect must be confined to that stated in the description are questions for the court itself to determine by construing the words of delegation in the light of the general object that the statute serves, the gravity of the mischief at which the subordinate legislation [i.e., the regulation] is aimed and the effect (if any) which it will have upon other lawful acts or property rights of citizens which neither cause nor contribute to that mischief. ${ }^{224}$

Both, moreover, thought that the Regulation was simply too vague to be valid: "A man must not be put in peril on an ambiguity under the criminal law."225 In essence, Lords Pearce and Diplock would have held the Regulation invalid because of overbreadth, because it was not reasonably calculated to deal with any existing emergency, and because it was too vague-just as an American court would probably have done.

Whether such views will prevail when and if another such case arises remains to be seen. The British Ministers for Northern Ireland have so far shown no disposition to use their powers under the 1973 Emergency Provisions Act in any such arbitrary fashion; the proscribed organizations-the I.R.A., the Ulster Freedom Fighters, and the like-have all been notoriously

222. He saw assurance against the Minister's going beyond the intent of Parliament in the Act's requirement that Regulations be laid before both Houses of Parliament, either of which could "pray" the Lord Lieutenant to annul it-although he cited no instance in which the Stormont Parliament had ever taken such exception to the Minister's actions.

223. Unlike Lord Guest, he thought he knew the significance of the word "republican" in Ulster: "A republican club in Northern Ireland is presumably one whose members believe in a republican form of government, and wish to have such a form of government introduced into Northern Ireland, which would naturally be effected by Northern Ireland being severed from the United Kingdom and incorporated in the Irish Republic." He did not advert to the fact that there was no claim that the purposes of the Slaughtneil Republican Club were seditious or otherwise unlawful.

224. [1971] A.C. 632,661 .

225. [1971] A.C. at 653 (Lord Pearce). 
violent. No British judge disputes the power of Parliament to do whatever it thinks fit, and British judges are still much inclined to put their trust in Parliament not to tolerate executive abuse of statutory powers. That trust was misplaced in the case of the former Parliament of Northern Ireland, and the Westminster Parliament has more than once resolved ambiguities by overruling decisions of the courts that limited executive discretion. But it is true that Parliament would be most unlikely explicitly to authorize really oppressive measures, such as the methods of interrogation disclosed by the Compton and Parker Reports; it seems probable that in the unlikely event that the Government were to argue that such methods were permitted by the 1973 Act (which, it will be recalled, outlaws only confessions obtained by "torture or ... inhuman or degrading treatment") ${ }^{226}$ the House of Lords would hold otherwise, and Parliament would acquiesce. In fact, however, there has been no litigation challenging executive action under the 1973 Act (or the Prevention of Terrorism Acts), and, with internment at an end, at least for the present, there appears to be none on the horizon. Moreover, it must be remembered that the Northern Ireland Constitution Act of 1973 exempts actions taken in the name of security from judicial review of measures that allegedly discriminate on religious or political grounds. ${ }^{227}$

What lessons has the British experience for this country? The first, of course, is that the political and legal process should be usable, and used, to prevent any such oppression of a minority as that which existed in Northern Ireland's one-party state. But men are not always rational, and courts may hold constitutional what some men see as oppression. Moreover, many or most terrorists prefer violence to the political and legal process. A situation like that in Northern Ireland is, I hope, unlikely to arise in any state; but it is not unimaginable. Indeed, something like it actually existed during the Civil War, in those Northern States where Copperhead sentiment was strong. We must ask, therefore, how far the law of the United States would permit its Government to go in suppressing violence too widespread and serious to be handled by ordinary means of law enforcement.

The Constitution of the United States empowers Congress "to provide for calling forth the Militia to execute the Laws of the Union, suppress Insurrections and repel Invasions." 228 The President "shall take care that the Laws be faithfully executed," 229 which may sometimes require the use of the armed forces, as in Little Rock in 1957. "The United States shall guarantee to every State in the Union a Republican Form of Government, and shall protect each of them against Invasion; and on Application of the Legislature, or of the

226. See note 147 supra, and accompanying text.

227. See notes 69,70 supra, and accompanying text.

228. Art. I, $\$ 8, \mathrm{cl} .15$.

229. Art. II, $\$ 3$. 
Executive [when the Legislature cannot be convened] against Domestic Violence." 230 But "the Privilege of the Writ of habeas corpus shall not be suspended, unless when in Cases of Rebellion or Invasion the public Safety may require it." 231

The Supreme Court has never decided whether the writ may be suspended only by Congress, or also by the President. Chief Justice Marshall expressed obiter the view that the power was to be exercised by Congress, ${ }^{232}$ and such judicial precedent as there is seems to support that view. ${ }^{233}$ But President Lincoln suspended the writ in the cases of persons detained by military authority before Congress finally gave him such power in $1863 .^{234}$ Chief Justice Taney, sitting alone as a Circuit Judge, held Lincoln's action invalid in the case of a secessionist who had been imprisoned on suspicion of planning to blow up railroad bridges between Baltimore and Washington. ${ }^{235}$ Taney's order was ignored, and the case went no farther. When Franklin Roosevelt in 1942 issued a proclamation which, in effect, denied the privilege of the writ to persons "who give obedience to or act under the direction" of any nation at war with the United States, the Supreme Court, holding that the arrest and trial by military commission of eight German saboteurs (one of them assumed to be an American citizen) were lawful, found it unnecessary to decide whether the President's unilateral suspension validly closed the courts to such people. ${ }^{236}$

There are three principal Acts of Congress which implement the powers given by the Constitution to Congress or the President to take extraordinary action in emergencies. They are, on their faces, at least as broad as any of the British statutes. Section 331 of Title 10 of the United States Code, which dates from 1792, provides that, "Whenever there is an insurrection in any State against its government ${ }^{237}$ the President may upon the request of its legislature

230. Art. IV, $\S 4$.

231. Art. I, $\$ 9$, cl. 2 .

232. Ex parte Bollman, 8 U.S. (4 Cranch) 75, 101 (1807). He did not, however, say explicitly that it could not also be exercised by the President.

233. See W. Winthrop, Military Law and Precedents 828-30 (2d ed. 1896); C. Fairman, supra note 4 , at 204-09.

234. C. Falrman, supra note 4, at 204-09.

235. Ex parte Merryman, 17 F. Cas. 144 (C.C.D.Md. 1861) (No. 9487). Although Taney may have been right in holding that the suspension of the writ was invalid and that he therefore had jurisdiction to consider the legality of Merryman's confinement, he was probably wrong in concluding that the emergency did not justify his internment, particularly in view of the fact that the prevalence of secessionist sentiment at the time and place would have rendered it virtually impossible to try and convict Merryman by the regular criminal process.

236. Ex parte Quirin, 317 U.S. 1 (1942).

237. For the purpose of the statute "domestic violence" so serious that it cannot be controlled by the state authorities, though it may be only rioting, looting, and arson not motivated by any considered purpose to overthrow the government, has been treated as "insurrection." See Letter from Attorney General Ramsey Clark to state governors (August 7, 1967), the text of which is set forth in Laird v. Tatum, 408 U.S. 1, 3 n.2 (1972). 
or of its governor if the legislature cannot be convened ... use such of the armed forces as he considers necessary to suppress the insurrection." Section 332, also dating from 1792 and revised in 1861, deals with situations in which state governments neither seek nor desire federal intervention:

Whenever the President considers that unlawful obstructions, combinations, or assemblages, or rebellion against the authority of the United States, make it impracticable to enforce the laws of the United States in any State . . by the ordinary course of judicial procceedings, he may ... use such of the armed forces as he considers necessary to enforce those laws or to suppress the rebellion.

Most sweeping of all is section 333, based on the Ku Klux Klan Act of $1871:^{238}$

The President, by using the militia or the armed forces, or both, or by any other means, shall take such measures as he considers necessary to suppress, in a State, any insurrection, domestic violence, unlawful combination, or conspiracy, if it-

(1) so hinders the execution of the laws of that State, and of the United States within the State, that any part or class of its people is deprived of a right, privilege, immunity, or protection named in the Constitution and secured by law, and the constituted authorities of that State are unable, fail, or refuse to protect that right, privilege, or immunity, or to give that protection; or,

(2) opposes or obstructs the execution of the laws of the United States or impedes the course of justice under those laws.

In any situation covered by clause (1), the State shall be considered to have denied the equal protection of the laws secured by the Constitution. ${ }^{239}$

These statutes have been invoked on many occasions, from the Whiskey Rebellion of 1794, through the violent labor disputes of the late nineteenth and early twentieth centuries, to the integration crises in Arkansas, Alabama, and Mississippi, and the urban riots of the late sixties, ${ }^{240}$ although their constitutionality has never been tested in court. ${ }^{241}$ Rarely in modern times has the President had to rely on whatever powers may under the Constitution be in-

238. Ku Klux Klan Act of 1871, c. 22, 17 Stat. 13 (Apr. 20, 1871).

239. 10 U.S.C. $\$ 333$ (1970).

240. See Office of Judge Advocate General, Federal Aid in Domestic Disturbances 1903-1922, S. Doc. No. 263, 67th Cong., 2d Sess. (1922); Campisi, The Civil Disturbance Regulations: Threats Old and New, 50 IND.L.J. 757 (1975); University of Colorado Law Revision Center, A Comprehensive Study of the Use of Military Troops in Civil Disorders with Proposals for Legislative Reform, 43 U. Colo. L. Rev. 399, 400, 413 (1972) (discussing also state employment of the militia to control violence); Poe, The Use of Federal Troops to Suppress Domestic Violence, 54 A.B.A.J. 168 (1968); Wiener, Helping to Cool the Long Hot Summers, 53 A.B.A.J. 713 (1967).

241. The opinion has been expressed that sections 332 and 333 are unconstitutional on their faces. See Engdahl, The New Civil Disturbance Regulations: The Threat of Military Intervention, 49 IND.L.J. 581 (1974). In my own opinion, the constitutionality of an executive action under these congressional grants of authority would be governed by the test laid down in Sterling v. Constantin, 287 U.S. 378 (1932). See note 262 infra. 
herent in his office, at least for the preservation of "domestic Tranquillity." 242 Franklin Roosevelt, like Lincoln, made free use of his powers as Commander in Chief after the outbreak of World War II, but before Pearl Harbor. ${ }^{243}$ The exclusion, shortly thereafter, of American citizens of Japanese descent from the West Coast and their internment in "relocation centers" was initiated by an Executive Order of the President, which, however, was shortly ratified by an Act of Congress. ${ }^{244}$ But when Harry Truman attempted to avert a steel strike during the Korean War by seizing all the steel plants, the Supreme Court held his action invalid, largely because Congress, when enacting the Taft-Hartley amendments to the National Labor Relations Act, had deliberately refused to grant the President such power. ${ }^{245}$

There is, however, one statutory restriction on the freedom of American civil authorities to call upon the military for help. The Posse Comitatus Act of 1879 , originally enacted to end the use of federal troops to enforce the Reconstruction Acts in the former Confederate states, in its present form in substance forbids the use of the Army or Air Force "to execute the laws . . . except in cases and under circumstances expressly authorized by the Constitution or Act of Congress." 246 If federal troops are required to enforce the law, the President must invoke his powers under sections 331-333 of Title $10^{247}$ or under the Constitution.

It should also be remarked that there has never been any equivalent to the British "Joint Directive on Military Interrogation in Internal Security Operations" 248 in the published regulations of the United States Armed Forces,

242. In an opinion upholding the legality of President Eisenhower's use of the Army (including the Arkansas National Guard, which had been called into federal service) in Little Rock, the Attorney General cited sections 332 and 333 of Title 10, but added that "there are... grave doubts as to the authority of the Congress to limit the constitutional powers of the President to enforce the laws and preserve the peace under circumstances which he deems appropriate." 41 Op. Att'y. Gen. 313 (1957). In the last century the Supreme Court on more than one occasion emphatically upheld the President's inherent power to use as much force as necessary to enforce federal law. E.g., In re Debs, 158 U.S. 564, 582 (1895); Ex parte Siebold, 100 U.S. 371,395 (1880).

243. E.g., the destroyers-for-bases swap, the occupations of Greenland and Iceland, the use of the Navy to convoy vessels carrying supplies to England, and the order to the Army and Navy to attack German submarines in American "defensive waters." See Schaffter \& Mathews, The Powers of the President as Commander in Chief of the Army and Navy of the United States, H.R.Doc.No. 443, 84th Cong., 2d Sess. (1956).

244. See Hirabayashi v. United States, 320 U.S. 81 (1943); Rostow, The Japanese-American Cases-A Disaster, 54 YALE L.J. 489 (1945).

245. Youngstown Sheet \& Tube Co. v. Sawyer, 343 U.S. 579 (1952).

246. 18 U.S.C. \& 1385 (1970). See, e.g., United States v. McArthur, 419 F. Supp. 186 (D.N.D. 1976) and cases cited; United States v. Red Feather, 392 F. Supp. 916 (D.S.D. 1975) and cases cited; Furman, Restrictions Upon Use of the Army Imposed by the Posse Comitatus Act, 7 MiL.L.REv. 85 (1960); Meeks, Illegal Law Enforcement: Aiding Civil Authorities in Violation of the Posse Comitatus Act, 70 MiL.L. REv. 83 (1975).

247. See notes 237-241 supra, and accompanying text.

248. See note 107 supra, and accompanying text. 
which in modern times have not had to deal with domestic terrorists. American troops in Vietnam were regularly instructed to treat captives, including members of both the North Vietnamese armed forces and the Viet Cong, in strict accordance with the requirements of the Geneva Convention. ${ }^{249}$ If captives under interrogation by American intelligence agencies were subjected to such treatment, as in all probability they sometimes were, it was without any form of express governmental direction or sanction. Generally, the United States Armed Forces appear to follow the same rule as the British in the use of force to control civil disorders: No more force may be used than the minimum required to control the violence. ${ }^{250}$ The use by American forces of techniques like those disclosed in the Compton and Parker Reports would presumably be as illegal as it was in Northern Ireland.

But, as we have seen, the Constitution gives to the President and Congress powers to preserve "domestic Tranquillity" that can be read very broadly indeed, and Congress, particularly in section 333 of Title 10, has given the President powers which, on their face, seem nearly unlimited. As Justice Jackson said in the Steel Case:

When the President acts pursuant to an express or implied authorization of Congress, his authority. . . includes all that he possesses in his own right plus all that Congress can delegate. In these circumstances, and in these only, may he be said (for what it may be worth) to personify the federal sovereignty. If his act is held unconstitutional under these circumstances, it usually means that the Federal Government as an undivided whole lacks power. ${ }^{251}$

We cannot count on a Lincoln in the White House when the next great emergency occurs. If Congress and the President go too far, imposing greater restrictions on civil liberty or authorizing more force than the emergency requires, who can curb them? In the United States, of course, the answer is clearer than it is in the United Kingdom: the Supreme Court can, and sometimes has, put constitutional limits on the actions taken by Congress and the President to deal with war and other emergencies. A survey of the Court's major decisions suggests that it resembles the House of Lords in one important respect: its willingness to intervene varies in inverse ratio to the decision's chronological closeness to the emergency. During the Civil War the Court managed not to decide whether President Lincoln's internment and military

249. See, e.g., G. Prugh, Law at War: Vietnam 1964-73, at 74-76 (Dept. of the Army 1975).

250. "When Federal military forces are employed in the United States and its territories, whether or not martial law prevails, the acts of individual military personnel are subject to review by the civil courts in actions for damages or in criminal proceedings." The orders of a superior are not a defense "if the illegality of the act is so obvious as to be immediately apparent to a person of average intelligence." Department of the Army. Field Manual 19-15. Civil. Disturbances and Disasters 3-7 (1968). See Murray, Civil Disturbance, Justifiable Homicide, and Military Law, 54 Mil..L.REv. 129 (1971).

251. Youngstown Sheet \& Tube Co. v. Sawyer, 343 U.S. 579. 635 (1952). 
trials of secessionist sympathizers were unconstitutional, ${ }^{252}$ or whether the Constitution permitted him to suspend the writ of habeas corpus. But shortly after the last Army of the Confederacy had surrendered, a majority of the Court held in ringing terms, in Ex parte Milligan, that neither Congress nor the. President could in any circumstances authorize military trial of a civilian at a time and in a place (specifically, Indiana in 1864) where the civilian courts were open. ${ }^{253}$ In 1942, with the war against Germany and Japan at a crisis point and not going very well for the Allies, the Court held that an American civilian, sent into the United States by the Nazi government to commit sabotage, could be tried for a violation of the laws of war by a military commission sitting in the United States, although the civilian courts were, of course, open and functioning. ${ }^{254}$ Milligan was distinguished on several grounds, of which only one-that the Nazi saboteur was an agent of an enemy government, whereas Milligan had no authority from the Confederacy-seems to me to have any plausibility. ${ }^{255}$

Early in 1943 the Court unanimously held constitutional the imposition of a curfew on American citizens for no other reason than that they were of Japanese descent. ${ }^{256}$ In the next year, with the Japanese Empire looking less formidable, a divided Court upheld the deportation of such citizens from their homes on the West Coast and their internment in "relocation centers," 257 although in another case decided at the same time all the Justices drew the line at interning a citizen, concededly loyal, solely because she had not succeeded in finding a place to go where "community sentiment" was not hostile to Japanese Americans. ${ }^{258}$ Shortly after the end of the war, the Court held that the state of martial law that had existed in Hawaii from December 7 ,

252. The two cases which came closest to presenting the issue were Ex parte Merryman, $17 \mathrm{~F}$. Cas. 144 (C.C.D. Md. 1861) (No. 9487) and Ex parte Vallandigham, 68 U.S. (1 Wall.) 243 (1863). In the former, the Government, instead of appealing the order of Chief Justice Taney (sitting as a Circuit Judge) to release an interned secessionist, simply ignored it. See note 235 supra, and accompanying text. In the latter Lincoln mooted the issue of the constitutionality of a military commission's sentence of a Copperhead leader to imprisonment, by releasing him and sending him behind the Confederate lines. Habeas corpus was no longer an appropriate remedy, and there was then (and is now) no direct appeal to the Supreme Court (or any other civil court) from the verdict of any kind of military tribunal.

253. 71 U.S. (4 Wall.) 2 (1866). Chief Justice Chase and three of his brethren concurred only on the ground that Congress had not in fact authorized such trials.

254. Ex parte Quirin, 317 U.S. 1 (1942). One of the petitioners. Herbert Hans Haupt. was assumed by the Court to be an American citizen. Since the Court decided against the petitioners on the merits, it was able to bypass the issue of the constitutionality of President Roosevelt's suspension of habeas corpus in such cases.

255. See J. Bishop, Justice Under Fire: A Study of Military Law 195-96 (1974).

256. Hirabayashi v. United States. 320 U.S. 81 (1943).

257. Korematsu v. United States, 323 U.S. 214 (1944).

258. Ex parte Endo, 323 U.S. 283 (1944). Strictly, the decision was that neither the Act of Congress nor the Executive Order authorized internment for such a reason. but Justice Douglas talked the language of the Constitution. 
1941 to October 24, 1944 (without challenge in the Supreme Court) did not justify the trial of civilians by military courts. ${ }^{259}$ Justices Burton and Frankfurter, dissenting, thought the case would have gone the other way had it reached the Court "with the war against Japan in full swing."260

The rules the Supreme Court would, I hope and believe, apply if the United States were faced with a situation like that in Northern Ireland, and if Congress and the President were to resort to some or all of the measures employed by the British Government, are best stated in two decisions of the Supreme Court, the first by Chief Justice Taney in 1852 and the second by Chief Justice Hughes eighty years later. In Mitchell $v$. Harmony, ${ }^{261}$ which involved the legality of the seizure by a military officer, during the Mexican war, of a citizen's property, Taney said, "Every case must depend on its own circumstances. It is the emergency that gives the right, and the emergency must be shown to exist before the taking can be justified." In Sterling v. Constan$\operatorname{tin},{ }^{262}$ in which the Court invalidated a state governor's declaration of martial law and his order to the state militia to prevent the enforcement of a federal court's order, Hughes (after quoting Taney) said, "What are the allowable limits of military discretion, and whether or not they have been overstepped in a particular case, are judicial questions." These basic criteria were restated by the Supreme Court in 1974, in a case holding that the actions of the Governor of Ohio and the state miliita in the disturbances, culminating in the shooting by militiamen of four students, at Kent State University, were not beyond judicial review. ${ }^{263}$ The latter two, of course, dealt with state governments, but the fundamental tests seem equally applicable to the United States.

These cases involved forms of military action, and in none did the Court find clear-cut congressional authority for what was done, but the concept that the actions of Congress or the President, or both, can be no more drastic than is required to deal with an actual emergency has been applied in other contexts. Thus, when the Court in 1967 struck down a provision of the Subversive Activities Control Act of 1950, which made it unlawful for a member of a Communist organization "to engage in any employment in any defense facility," it did so on the ground that the prevention of espionage and sabotage, though it could be accomplished under "narrowly drawn" legislation, did not require a blanket exclusion of Communists from every sort of job in the defense

259. Duncan v. Kahanamoku, 327 U.S. 304 (1946). Again the actual holding was that the state of "martial law" which was authorized by the Hawaiian Organic Act was not intended to include the trial of civilians by military courts. But the Court's reliance on Ex parte Milligan, 71 U.S. (4 Wall.) 2 (1866), suggests that the holding really rested on the Constitution.

260. 327 U.S. at $337,357$.

261. 54 U.S. (13 How.) 115 (1852).

262. 287 U.S. 378 (1932). See Fairman, Martial Rule In the Light of Sterling v. Constantin, 19 Cornell L.Q. 20 (1933).

263. Scheuer v. Rhodes, 416 U.S. 232 (1974). 
industry, without regard to the particular Communist's inclination or opportunity to engage in such activities. ${ }^{264}$ Otherwise stated, the Constitution gives Congress and the President "the least possible power adequate to the end proposed."265

Under such tests, would Congress have the power to deal with violence like that in Ulster with a statute like the Emergency Provisions Act of 1973? As to internment, the answer is probably yes, if the Court found that there was a real emergency and that circumstances made it impractical to lock up terrorists by the ordinary criminal process. A well-known decision by Justice Holmes upheld the power of a state governor to intern without trial one suspected of organizing large-scale violence, ${ }^{266}$ and although Hughes' opinion in Sterling $v$. Constantin ${ }^{267}$ moderated Holmes' sweeping language, he also indicated that the result in that case was justified under the test laid down in his own decision. The Japanese Exclusion Cases ${ }^{268}$ in effect upheld mass internment in circumstances arguably less exigent than those in Ulster. Even Justice Davis, speaking for the majority in Milligan, said that "Unquestionably there [may be] an exigency which demands that the government, if it should see fit in the exercise of a proper discretion to make arrests, should not be required to produce the person arrested in answer to a writ of habeas corpus." 269 Justice Black emphasized in Duncan $v$. Kahanamoku that the decision did not affect "the power of the military simply to arrest and detain civilians interfering with a necessary military function at a time of turbulence and danger from insurrection or war." 270

The constitutionality of criminal trials without a jury (for offenses more than "petty," carrying a penalty of more than six months' confinement) seems to me a more doubtful question. In this country, unlike England, resort has traditionally been had to military tribunals in circumstances that are believed to make civilian criminal trials by jury impractical. Milligan and Duncan suggest that civilians cannot be tried by such courts when the civilian courts are "open." But suppose that the probable bias of jurors, and the intimidation of both jurors and witnesses, makes it impossible for the civilian courts to function in a normal way. Charles Evans Hughes, speaking off the bench, suggested that the "open court" language of Milligan should not be applied too literally: "Certainly, the test should not be a mere physical one, nor should substance be sacrificed to form."271 Quirin suggests that the Supreme Court, in

264. United States v. Robel, 389 U.S. 258 (1967).

265. See, e.g., United States ex rel. Toth v. Quarles, 350 U.S. 11, 23 (1955); Anderson v. Dunn,

19 U.S. (6 Wheat.) 204, 230-31 (1821).

266. Moyer v. Peabody, 212 U.S. 78 (1909).

267. 287 U.S. 378 (1932).

268. See notes 256-258 supra and accompanying text.

269. 71 U.S. at $125-26$.

270. 327 U.S. at 314 .

271. Hughes, War Powers Under the Constitution, 42 A.B.A.REP. 232, 245 (1917). 
what it perceives as a great emergency, can find ways to distinguish Milligan, and probably Duncan as well. If trials by military commission, which may not follow any of the usual rules of procedure, evidence, or appeal, are permissible, there seems to be a stronger case for something like "Diplock courts"that is, a district court sitting without a jury, but adhering as closely as circumstances permit to the ordinary rules of evidence and criminal procedure.

In short, I would not give an unhedged opinion that the Supreme Court in a situation of actual armed insurrection like that in Northern Ireland, which could not be controlled by the normal methods of law enforcement, would not permit civilian courts to try terrorist crimes without a jury and with some relaxation of the usual rules of proof and evidence. Even legislation making membership in a terrorist organization a crime might be constitutional, at least if there were substantial evidence of the organization's violent purpose and if the legislation were treated as a device to facilitate proof of the crime of conspiracy. Finally, we should not forget that article III of the Constitution provides that "the Supreme Court shall have appellate jurisdiction ... with such Exceptions, and under such Regulations as the Congress shall make." Under the Reconstruction Act of March 2, 1867, ${ }^{272}$ military commissions continued, after Milligan, to try civilians in the former Confederate states. ${ }^{273}$ When Congress withdrew such cases from the Court's jurisdiction, the Justices chose not to precipitate a constitutional confrontation. ${ }^{274}$ One may hope that these questions will remain academic, but it does no harm to think about them before they actually arise.

To an American lawyer the Constitution, enforceable by the courts, seems to offer better assurance that emergencies will not engender unnecessary encroachments on civil liberty than does the British trust in the self-restraint of the Government and the Parliament. There are today in England strong advocates of a Bill of Rights on the American model, placing bounds enforceable by the courts on the power of Parliament. ${ }^{275}$ There are even suggestions that the European Convention on Human Rights, to which the United Kingdom is, of course, a signatory, already amounts to exactly that-specifically, that if the Court of Human Rights are to hold an Act of Parliament in contravention of the Convention and Parliament refused to repeal it, the

272. 14 Stat. 428 .

273. The Attorney General opined that this provision of the Reconstruction Act was constitutional, distinguishing Milligan on the ground that these states, until such time as they created constitutions and governments acceptable to Congress, were still occupied enemy territory, in which Milligan had conceded that military government courts could try civilians. Case of James Weaver, 13 Op. Att'y Gen. 59 (1869).

274. Ex parte McCardle, 74 U.S. (7 Wall.) 506 (1869).

275. Lord Justice Scarman, for example, has called for "a fundamental law, a Bill of Rights where it is the duty of the courts to protect people against the powers of Parliament." The Times (London) Dec. 6, 1974, at 4, col. 5. See also Tне Economist, July 12, 1975, at 25-26. 
courts of England should refuse to enforce that statute. ${ }^{276}$

It is doubtful that either the Parliament or the judges of England are yet ready for such doctrines. They obviously raise, as they have sometimes done in this country, the specter of the courts' setting themselves up as supreme lawgivers, usurping powers belonging to the other two branches. But that risk may be less than the risk of placing no limit at all upon the power of Parliament to curtail the rights of the subject in emergencies. The record of the United States Supreme Court strongly suggests that in genuine emergencies, when some liberties must temporarily be suspended in order that all liberties may not be lost, the courts would not be zealous to impose unrealistic limits on the judgment of the Government and Parliament.

276. See Mann, The United Kingdom's Bill of Rights, 122 NEw L.J. 289 (1972). Lord Kilbrandon's opinion in Broome v. Cassell \& Co., [1972] A.C. 1027, 1133 spoke of "what must be regarded, at least since the European Convention was ratified, as a constitutional right to free speech." 
HeinOnline -- 42 Law \& Contemp. Probs. 2021978 